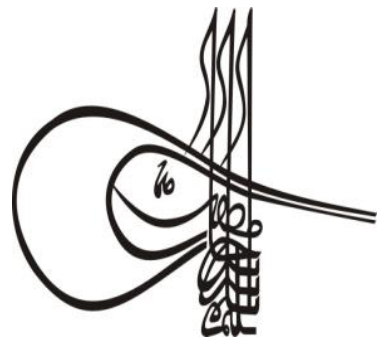

Received/Geliș: 04.01.2019

\section{Turkiglo Studieg Historical Analysis}

Volume 14 Issue 2, 2019, p. 327-357

DOI: 10.29228/TurkishStudies.22531

ISSN: 2667-5552

Skopje/MACEDONIA-Ankara/TURKEY

Research Article / Araştırma Makalesi

Article Info/Makale Bilgisi

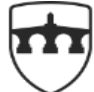

INTERNATIONAL BALKAN UNIVERSITY

EXCELLENCE FOR THE FUTUR IBU.EDU.MK

Gor Report Dates/Rapor Tarihleri: Referee 1 (19.01.2019)-Referee 2 (09.04.2019)- Referee 3 (21.05.2019)

This article was checked by iThenticate.

\title{
SİYASİ VE HUKUKİ AÇIDAN 1961 ANAYASASI'NDA YAPILAN DEĞİŞİKLİKLER (1969-1974)
}

\author{
Mustafa SALEP*
}

\section{ÖZ}

1961 Anayasası, Türk siyasi tarihi ve anayasal süreç açısından son derece önemli bir metindir. 27 May1s Darbesinden sonra Kurucu Meclis tarafından hazırlanmış olan ve halkoyu ile kabul edilen 1961 Anayasası, siyasi ve toplumsal alanda üzerinde hassasiyetle durulan bir konu olmuștur. Antidemokratik bir atmosferde hazırlanmıș olmasına rağmen, hürriyetçi ve özgürlükçü bir içeriğe sahip olması, 1961 Anayasası'nı diğer anayasa metinlerinden ayıran önemli bir özelliktir. Anayasanın bu özelliği, ilerleyen yıllarda çeșitli eleștirileri de beraberinde getirmiștir. Bu çalışmada 1961 Anayasası'na yöneltilen eleștiriler, anayasa üzerine yapılan tartışmalar ve 1969- 1974 yılları arasında anayasada yapılmış olan değişiklikler siyasi ve hukuki açıdan incelenmiştir. Belirtilen yıllarda yedi kez değişikliğe uğrayan 1961 Anayasası, ilk ana metinden önemli oranda farklılaşmıştır. Adalet Partisi'nin tek başına iktidarda olduğu 1965- 1971 yılları arasında anayasada ciddi bir değişiklik olmamış, esas değişiklik ise 12 Mart 1971 Muhtırasından sonra gerçekleştirilmiştir. Türkiye'nin özellikle 1967- 1971 yılları arasında karşılaşmış olduğu siyasal ve toplumsal sorunların anayasa değissikliklerinde etkili olduğu söylenebilir. 1961 Anayasası'nın hazırlanmasını sağlayan Türk Silahlı Kuvvetleri, 12 Mart Muhtırası ile siyasete müdahalede bulunmuş ve 1961 Anayasası'nın büyük oranda değiștirilmesinde de en etkin rolü üstlenmiştir. 1971 yllından sonra yapılan anayasa değişikliklerinde özellikle kamu düzeninin korunması ve milli güvenliğin sağlanmasının amaçlandığ1 söylenebilir. Bu bağlamda kişi hak ve özgürlüklerinin sınırları belirlenmiştir. Çalışmada arşiv kaynakları, resmi kayıtlar, gazeteler, hatıralar ve tetkik eserler kullanılmış olup, çalışmanın siyasi tarihimize ve anayasal birikimimize katkı sağlaması amaçlanmaktadır.

Anahtar Kelimeler: 1961 Anayasası, Silahlı Kuvvetler, 12 Mart Muhtıras1, Milli Güvenlik, 1969- 1974. 


\title{
AMENDMENTS ON 1961 CONSTITUTION FROM POLITICAL AND LEGAL POINT OF VIEW (1969-1974)
}

\begin{abstract}
1961 Constitution is an absolutely important text in terms of Turkish political culture and constitutional process. Prepared by the Founder Parliament in the aftermath of 27 May Coup and approved by the public, 1961 Constitution has always been of concern in political and social agenda. Although it was prepared in an anti-democratic atmosphere, it has a libertarian and pro-freedom content, which makes 1961 Constitution different from other constitutional texts. This characteristic of constitution brought about some criticism in the following years. The study analyzes the criticisms forwarded to 1961 Constitution, debates on this constitution and the amendments made throughout the years between 1969 and 1974 from a political and legal point of view. Having been amended for 7 times during these years, 1961 Constitution became quite different from the first main text. There were no considerable amendments during the single government of Adalet Party between 1965 and 1971, while the main difference was made after the 12 March 1971 Memorandum. It could be said that specifically the political and social issues faced by Turkey throughout the years between 1967 and 1971 played a significant role on these constitutional amendments. Turkish Armed Forces, who ensured that 1961 Constitution was prepared, made an intervention to Turkish policy through 12 March memorandum and played the most significant role in the amendment of 1961 Constitution to a great extent. It could be said that the constitutional amendments made after 1971 was specifically aimed at the protection of public order and establishment of national unity. In this context, the limitations to individual rights and freedom were identified. The study makes use of archival resources, official records, newspapers, memoirs and audit works (tetkik eser), and it is expected that the study will contribute to our political history and constitutional summation of knowledge.
\end{abstract}

\section{STRUCTURED ABSTRACT}

Although constitutional texts and practices have a long history in Turkey, constitutional texts prepared especially in the $20^{\text {th }}$ century directly affect the present day. After the first constitution of the new Turkish state established in Anatolia in 1921, the second constitution was prepared in 1924 and finally the 1961 Constitution, which constitutes the subject of our study, was drafted. Every new constitution is undoubtedly built on constitutional accumulation in its history. Finally, in the preparation of the 1961 Constitution, the previous Turkish constitutions were the mainstay of the study. On the other hand, contemporary constitutional developments have been taken into consideration in the preparation of this constitution. This constitution, which was prepared as a result of the coup of 27 May, was directly influenced by the political developments in the 1950-1960 period. The fact that the members of the Constituent Assembly, who drafted the 1961 Constitution, were witnesses to relevant political period supports this 
effect. The 1961 Constitution was finally adopted by a referendum held on 9 July 1961.

The Constitution of 1961 focused on personal rights and freedoms on issues such as fundamental rights and freedoms, working life, the right to form a trade union, the right to collective bargaining and strike, freedom of the press and communication, political rights, while some provisions of this Constitution were restrictive of executive authority and this caused great discussions in the period in which it was in force. The libertarian structure of the 1961 Constitution enabled the socialist sector to organize and strengthen until 1961, and this period paved the way for the formation of marginal organizations. In this period, where ideological goals were intense, there was an institutionalization ranging from political parties to associations and trade unions. These circles, which fully understood the content of the 1961 Constitution, frequently warned the political will on the implementation of the Constitution. On the other hand, events in this period started to disturb both the governments of the time and the majority of the society. All these events brought the issue of constitutional amendment to the agenda.

Seven amendments were made to the 1961 Constitution. The first amendment was made in November 1969, the last one in April 1974. The 1961 Constitution was composed of 157 main articles and 11 temporary articles. Throughout the period between from 1969 and 1974, 46 articles were amended, 12 provisional articles were added and 2 provisional articles were repealed in the 1961 Constitution,. The Constitutional Court, on the other hand, has annulled 4 of the amendments. Finally, we can say that the first version of the Constitution of 1961 has been significantly changed. The political and social developments in the 1960s paved the way for the constitutional amendments made especially after 1971. A significant part of the changes that the AP could not or could not have made during the reign of power were made after the March 12 Memorandum.

There was no change in the constitution between 1961 and 1965, when the coalition years were dominant, and three changes were made in 1965-1971, when the AP was in power alone. The first amendment to the constitution was dated November 6, 1969, with the removal of the obstacle to the ban on electoral deputies of politically banned DP members. This change was left after the 1969 elections for various political reasons. This amendment was annulled by the Constitutional Court's decision of 16 June 1970 and finally repealed by the Law no. 1801 of 16 April 1974. Thus, the political rights of DP people whose political rights were restricted during the 1960 s were restored.

The second and third amendments made during the period of EP rule were aimed at the regulation and conservation of forests on election dates. The most fundamental changes in the 1961 Constitution were made after the March 12 Memorandum. Although the memorandum did not include a constitutional amendment, the social and political conditions of the period led many sectors to focus on the constitutional amendment. Amendments were made in two articles in June 1971, 35 articles were amended on September 20, 1971 and 9 temporary items were added. Thus, the most fundamental change in the 1961 
Constitution was made in September 1971. The changes made directly affected the constitutional regime after 1961.

In the constitutional amendments made in September 1971, significant changes were made in the fundamental rights and freedoms section and it was accepted that the fundamental rights and freedoms could be restricted for the protection of national security and public order. For the same reasons, it was decided that newspapers and magazines could be confiscated. The period of detention without a judge's decision was increased to 48 hours and the concept of the natural judge was abandoned and the concept of legally applicable court was introduced. The Council of Ministers was given the authority to issue decrees by law, and the power of each deputy to submit a motion of no confidence was restricted. It can be said that the authority of the Council of Ministers has been increased. On the other hand, the wording as "notifies" regarding the decisions of the National Security Council to the Council of Ministers was abandoned and the term was changed as "recommends". Here, it is seen that the effect of the National Security Council on the executive is strengthened.

Another change in September was the abolition of civil servants' right to join trade unions. This decision can be seen as a decline in trade union rights. With the amendment made in the constitution, it is stated that university autonomy cannot prevent the prosecution of crimes and criminals in university buildings and annexes. Thus, it is emphasized that the government and law enforcement agencies can take necessary measures in universities in cases of criminal prosecution. On the other hand, it is understood that the one-month martial law authority of the Council of Ministers has been increased to two months. The Supreme Military Administrative Court was established and the conditions under which military courts could try non-military persons were explained. The provision that the Minister of Justice "may apply" to the Supreme Judges Council to initiate disciplinary proceedings against a judge has been corrected as "may request it to be opened." Thus, the influence of the Minister of Justice on judges and the Supreme Judges Council was increased.

On 15 March 1973, 5 articles were amended in the Constitution and 2 provisional articles were added to the text. One of the most important changes made here was the establishment of State Security Courts. Crimes against the Republic and state security are foreseen to be held in these courts. It was stated that the period of arrest could be extended up to 15 days for crimes falling under the jurisdiction of the State Security Courts. On 15 April 1975, the Constitutional Court annulled the provision that non-judges may also be members of the military courts in cases of war. Both changes show that the military judiciary is required to have an authoritarian structure. On the other hand, it was decided that the cases of closure of political parties could not be examined on file. Finally, with the amendment made on 16 April 1974, the political barriers to the amnesty after the sentence were removed.

It can be said that the 1961 Constitution has a libertarian content given political and social conditions of the period. Ensuring the rights and freedoms of individuals is undoubtedly contributing to the 
development of a culture of democracy. In this sense, we can say that the libertarian content of the 1961 Constitution, which was prepared in an antidemocratic process, was rich. On the other hand, the 1961 Constitution strengthened military and bureaucratic tutelage. Some institutions established by the Constitution aim to provide control of and domination over the political majority. This shows that the Constitution of 1961 has libertarian content on the one hand and restricts the powers of the political majority on the other. The social events that took place in the 1960s left the governments in a difficult position. These events forced the rulers of the period to make changes to the 1961 Constitution. Finally, with the amendments, the power of the executive was increased and the military bureaucracy was strengthened. Even though the regulation on the rights and freedoms of individuals is considered as retrogression, it can be said that the changes made can be considered as normal when considered in terms of many chaos. A system focused on rights and freedom is undoubtedly the most fundamental feature of ideal management. Finally, we can say that this system can make sense unless people's rights and freedoms are abused, social chaos is triggered and freedom of people is restricted.

Keywords: 1961 Constitution, Armed Forces, 12 March Memorandum, National Security, 1969- 1974.

\section{GíRiș}

İnsanlık tarihi boyunca kurulan devletler, ülkelerini geleneksel birikimler yanında yazılı metinlerle yönetmişlerdir. Türk tarihinde Orhun Abideleri ile başlayan yazılı metin geleneği, devlet teşkilatının en temel unsuru olmuştur. Ortaya konulan yazılı metinler, devlet kurumlarının belirli bir düzende yönetilmesini sağlamış ve bu kurumların toplumla ilişkilerini belirlemiştir. Yazılı metinler kimi zaman kararname, kimi zaman ferman, kimi zaman da yasa olmuştur. Osmanlı Devleti'nin sınırlarının fetihlerle birlikte hızla genişlemesi, devlet yönetiminin belirli ilkeler doğrultusunda yürütülmesini zorunlu hale getirmiştir. Merkez ve taşradaki askeri ve idari makamlar tespit edilmiş, nihayet görevler belirlenmiştir. Bütün bunlar, idari ve hukuki bir sürecin sonucunda oluşturulmuştur.

Anayasal metinler konusunda özellikle 19. yüzyılda önemli gelişmelerin meydana geldiğini söyleyebiliriz. Bu bağlamda 1808 tarihli Sened-i İttifak, basit bir anayasa taslağı olarak değerlendirilse de kendisinden sonraki sürecin başlangıcı sayılabilir (Berkes, 2004: 138). Uygulanmamakla birlikte ittifak senedinde, vergilerin görüşülerek belirlenmesi usulü, parlamenter bir işaret olarak değerlendirilebilir (Akşin, 2017: 25- 26). 1839 tarihinde Tanzimat'ın ilanı ile birlikte, hukuk devleti ilkesinin gerçekleştirilmesi konusunda birçok adım atılmıştır. Burada padişah, kendi isteği ile yasama ve yargı yetkisini sınırlamıştır. Temel haklara saygı göstereceğini açıklayarak mutlak iktidarını sınırlamıştır (Bozkurt, 1994: 271- 272). Daha sonra ise Islahat Fermanı ile vatandaşlık temeli üzerine kurulu bir devletin oluşturulmasının amaçlandığı görülmektedir (Karpat, 2010: 33, 37). Bütün bu gelişmeler bir tarafa anayasal bir metin ancak, 23 Aralık 1876 tarihli Kanun-i Esasi ile ortaya konulmuştur. 1876 Anayasası da denilen Kanun-i Esasi, toplam 119 maddeden oluşmaktadır (KiliGözübüyük, 2006: 36- 51) ${ }^{1} .1876$ Anayasası'nın uygulanması belirli bir süre kesintiye uğramış olsa da, yeni Türk devletinin kurulmasına kadar etkisini sürdürmüştür.

\footnotetext{
${ }^{1}$ Kanun-i Esasi'de yer alan bölümler şunlardır: "Memalik-i Devlet-i Osmaniye”, "Tebaa-i Devlet-i Osmaniye'nin Hukuk-i Umumiyesi”, "Vükela-yı Devlet", "Memurin", "Meclis-i Umumi”, "Heyet-i Ayan”, "Heyet-i Mebusan”, "Mehakim”, "Divan1 Ali", "Vilayat" ve "Mevadd-1 Şetta".
} 
Birinci Dünya Savaşı sonrası Milli Mücadele ile bağımsız yeni bir devlet kurma kararında olan Türk Milleti, 23 Nisan 1920'de Büyük Millet Meclisi'nin açılması ile Anadolu'da resmi bir temsile kavuşmuştur. Hakimiyetin kayıtsız ve şartsız millete ait olduğunu ilk maddesiyle açıklayan Teşkilat-1 Esasiye Kanunu ise, 7 Şubat 1921 tarihli Ceride-i Resmiye'de yayımlanmıştır (Ceride-i Resmiye, 7 Şubat 1921: 1; Kili- Gözübüyük, 2006: 105). Teşkilat-1 Esasiye Kanunu ile Anadolu'da kurulan yeni Türk devletinin ilk anayasas1 oluşturulmuştur (Tosun, 1997: 41). Bu Kanun, aynı zamanda 1921 Anayasası olarak da adlandırılmaktadır. 1921 Anayasası'nın hükümlerine bakıldığında; yönetim sisteminin adının henüz konulmadığı, ancak millet egemenliğine dayanan bir sistemin tercih edildiği anlaşılmaktadır (Kili, 2001: 267- 268). Nihayet bu anayasa, 1924 Anayasası'na kadar yürürlükte kalmış ve bir kısım değişikliklere uğramıştır (Kili- Gözübüyük, 2006: 119- 124).

Cumhuriyetin ilanından sonra 20 Nisan 1924'te kabul edilen ve 24 Mayıs 1924 tarihli Resmi Ceride'de yayımlanan 491 sayılı Teşkilat-1 Esasiye Kanunu ile, Türkiye Devleti'nin yönetim şeklinin cumhuriyet olduğu birinci maddede vurgulanmıştır (Resmi Ceride, 24 Mayıs 1924: 4). Bu Kanun ise 1924 Anayasası olarak adlandırılmıştır. Bu Anayasa, 1961 Anayasası'na kadar 37 yıl yürürlükte kalmış olmakla birlikte, beş kez değişikliğe uğramıştır (Koçak, 2011: 138; Kili- Gözübüyük, 2006: 127; Kili, 2001: 284). 27 Mayıs 1960 tarihli askeri darbeden sonra Meclis'in yetkileri, geçici 1 sayılı Kanunla Milli Birlik Komitesi'nin eline geçmiştir (Resmi Gazete, 14 Haziran 1960: 1533). Geçici 1 sayılı Kanun ise, 1961 Anayasası'nın kabulüne kadar yürürlükte kalmıştır. Bütün bu bilgiler, 1961 Anayasası'na kadar olan anayasal sürecin kısa bir özeti olarak değerlendirilebilir.

\section{1961 Anayasası’nın Kabulünden Sonra Anayasa Değişikliği Konusunda Yapılan Tartışmalar}

27 Mayıs 1960 tarihli askeri darbeden sonra oluşturulan Kurucu Meclis'te yeni anayasa çalışmaları hız kazanmış, Temsilciler Meclisi ve Milli Birlik Komitesi'nde yapılan uzun görüşmeler neticesinde anayasa tamamlanmıştır. Nihayet, Kurucu Meclis'in 27 Mayıs 1961 tarihli toplantısında, bütün maddeleri görüşülmüş olan anayasa tasarısı açık oya sunulmuş ve kabul edilmiştir (KMTD, 27 Mayıs 1961: 109; Son Havadis, 29 Mayıs 1961: 1)². Kabul edilen bu anayasa, 9 Temmuz 1961 tarihinde halkoyuna sunulmuştur (Son Havadis, 10 Temmuz 1961: 1; Milliyet, 10 Temmuz 1961: 1; Tunçkanat, 1996: 410; Çavdar, 1996: 102; Batur, 1985: 97; Yazıc1, 1997: 72)33. 9 Temmuz 1961'de kabul edilen Türkiye Cumhuriyeti Anayasası, nihayet 20 Temmuz 1961'de 334 sayılı Kanun numarası ile Resmi Gazete'de yayımlanmıştır (Resmi Gazete, 20 Temmuz 1961: 4641; Kili- Gözübüyük, 2006: 191). 9 Temmuz 1961'deki halk oylaması ile kabul edilen bu anayasa, 1961 Anayasası olarak anılmakta olup, bu çalışma içerisinde de ağırlıklı olarak bu ifade kullanılmıştır.

27 Mayıs 1960 darbesinden sonra hazırlanmış olan 1961 Anayasası'nın askeri ve sivil bürokratik vesayetin kurumsallaşmasına aracılık ettiği söylenebilir. Anayasa değişikliği üzerine yapılan tartışmalara geçmeden önce bu konuya da kısaca değinmenin yararlı olacağını düşünüyorum. $\mathrm{Bu}$ bağlamda, 1961 Anayasası ile oluşturulan çift meclisli yapının askeri vesayeti kuvvetlendirdiği söylenebilir. Cumhuriyet Senatosu'nun yasama faaliyetlerinde kontrol vazifesi görmesi ve Milli Birlik Komitesi üyelerinin Senatoda tabii üye olmaları, askeri vesayetin yasama içerisindeki varlığını göstermektedir (Akınc1, 2014: 62). 1961 Anayasas1 ile yürütme erkine kıyasla yarg1 erkinin kuvvetlendirildiği görülmektedir. Bu kapsamda Askeri Yarg1 ve Askeri Yargıtay anayasal bir statü kazanmış ve yürütmeden daha etkin bir pozisyona yerleşmiştir. 1961 Anayasası ile kurulan diğer bir kurum ise, Anayasa Mahkemesi olmuştur. Bu mahkemeyle, resmi ideolojinin kuvvetlenmesi sağlanmıştır. Yasama ve yargı erkinin yürütmeye göre daha etkin k1lınması, yürütmeye olan güvensizliğin bir işareti sayılabilir (Akıncı, 2014: 63- 64). 1961 Anayasası ile kurulan bir başka kurum

\footnotetext{
${ }^{2} 262$ kişinin oy kullandığı yeni anayasa, 2 çekimser oya karşılık 260 oyla kabul edilmiştir.

39 Temmuz 1961 tarihli anayasa referandumuna katılım oranı \% 81.05 olarak gerçekleşmiş, geçerli oyların \% 61.74'ünün “evet” oyu olarak kullanıldığı, \% 38.26'sının ise "hayır" oyu olarak kullanıldı̆̆ı anlaşılmaktadır.
} 
ise, Milli Güvenlik Kurulu'dur. Bu kurum ile askerler, siyasi parti temsilcileri üzerinde etkili olmuşlar ve baskı unsuru olarak varlıklarını sürdürmüşlerdir. Milli Güvenlik Kurulu kararları, başlangıçta Bakanlar Kuruluna görüş şeklinde bildirilirken, anayasada yapılan değişiklikle tavsiye şekline dönüştürülmüştür. Böylece, Milli Güvenlik Kurulunun yürütme üzerindeki gücünün artırılması amaçlanmıştır (Akıncı, 2013: 101- 103). 1961 Anayasal ortamı ile ordunun siyasi iktidarın emrinde bir kurum olmaktan çok, siyasi iktidarı kontrol edebilen ve siyasi iktidara direktifler verebilen bir kurum haline geldiği anlaşılmaktadır (Çolak- Akıncı, 2018: 62). Nihayet 1961 Anayasası ile askeri bürokratik elit yasama, yürütme ve yargı erkleri üzerinde önemli bir güç elde etmiştir.

1961 Anayasası üzerine yapılan tartışmalara geçecek olursak, 1961 Anayasası'nın özellikle sosyal konulardaki içeriğinin tartışmaları başlattığı söylenebilir. Anayasadaki sosyal devlet anlayışı, bir kesim tarafindan sosyalist devlet olarak yorumlanırken, çoğunluk kesim böyle bir yorumlamanın mümkün olmadığını belirtmiştir. Bu kapsamda Behice Boran, 1961 Anayasası'nın sosyalist harekete ve sosyalist temelli kalkınma planına açı olduğunu belirtmiş, kapitalizmin karşısına sosyalizm alternatifi konulmadıkça Batı örneğinde demokrasinin olamayacağını savunmuştur (Boran, 1992: 81, 102). Yine Mihri Belli de 1961 Anayasası ile ilgili değerlendirmelerde bulunmuş ve şunları söylemiştir: "1961 Anayasası, milli bir nitelik taşıyan ve dolayısıyla ilerici bir nitelik taşıyan asker- sivil aydın zümrenin, işbirlikçi sermaye ve feodal ağa gibi milli nitelik taşımayan emperyalizmin emrindeki sınıfları geriletmesini temsil eder (Belli, 2000: 540; Belli, 1970: 105)." Süleyman Demirel ise, 1961 Anayasası'nda yer alan sosyal devlet anlayışının sosyalist devlet anlamına gelmediğini belirtmiştir (Demirel, 1973: 286). Diğer taraftan dönemin önemli simalarından Osman Bölükbaşı, 1961 Anayasası ile ilgili olarak İzmit’te şunları söylemiştir: "İlk olarak size açıklıyorum. Osman Bölükbaşı Kurucu Meclis'i tasvip etmemiştir. O Meclis' in çıkardığı Anayasaya da itiraz eden adamdır" demiştir (Milliyet, 25 Haziran 1962: 1).

1961 Anayasası'nın sosyalizme açık olup olmadığı konusuna ait tartışmalar, 1960'lı yıllar boyunca devam etmiştir. Başbakan Süleyman Demirel, 30 Haziran 1967'de anayasanın sosyalizme kapalı olduğunu bir kez daha belirtmiştir (Soner, 2008: 39). Dönemin Cumhurbaşkanı Cevdet Sunay'ın da anayasanın sosyalizme kapalı olduğuna dair yorumu, hem sağ partileri hem de yüksek komuta kademesini destekler mahiyette olmuştur (Ahmad, 2010: 252). Cumhurbaşkanı Sunay'ın anayasanın sosyalizme kapalı olduğuna dair sözlerine karşı CHP Genel Sekreteri Bülent Ecevit ise, 5 Kasım 1967'de bir açıklama yaparak anayasanın sosyalizme açık olduğunu belirtmiştir (Soner, 2008: 47). Bütün bunlar, 1961 Anayasası'nın içeriği ve kapsamı ile ilgili farklı değerlendirmelerin olduğunu göstermektedir.

1961 Anayasası'nın özgürlükçü yapısı bir kesim tarafından olumlu olarak yorumlanırken, diğer bir kesim ise aşırı özgürlüklerin yıkıcı eylemleri doğurduğunu vurgulamıştır (Gevgilili, 1987: 191). 1961 Anayasası üzerine özellikle 1965 sonrasında yoğun tartışmaların yaşandığını söyleyebiliriz. Adalet Partisi'nin (AP) tek başına iktidarda olduğu bu dönemde, özellikle muhalif parti temsilcilerinin hükümeti anayasal içerik ve uygulamalar üzerinden eleştirdiğini görmekteyiz. Bu bağlamda, Millet Partisi (MP) Grup Başkanvekili Konya Milletvekili Seyyid Faruk Önder'in telefon konuşmalarının hükümet tarafından dinlendiği ve anayasanın 17. maddesinin ihlal edildiği iddiasına dair Ulaştırma Bakanı hakkında vermiş olduğu gensoru önergesi, Millet Meclisi'nde görüşülmüştür (Cumhuriyet, 19 Mart 1966: 1).

1961 Anayasası'nın işçilere tanıdığı haklardan birisi de grev hakkıdır. Türkiye İşçi Partisi (TIP) Karşıyaka İlçe Teşkilatı, 7 Şubat 1966'da cereyan eden Kula Fabrikasındaki grevle ilgili TíP Ankara Milletvekili Rıza Kuas ve Tekirdağ Milletvekili Kemal Nebioğlu'nun yapmış olduğu basın toplantısını kamuoyuna açıklamıştır. Yapılan açıklamada, TİP'in anayasanın tastamam uygulanması için çalıştığı vurgulanmıştır. Yükselen fiyatlar karşısında işçilerin ücretlerinin yükselmediğinin belirtildiği açıklamada, hükümetin işçi ve işveren ilişkilerinde tarafsız kalmak yerine çalışanlardan ve ezilenlerden yana tavır alması gerektiği belirtilmiştir (Türkiye İşçi Partisi Karşıyaka İlçesi Yönetim Kurulu, 1966: 
1) ${ }^{4}$. Başbakan Süleyman Demirel ise, grevin modern devletin bir icabı olduğunu belirtmiş, Anayasada yer alan haklara riayete mecbur olduklarını vurgulamıştır. Demirel ayrıca, kanunların imkan verdiği ölçüde hakların kullanılmasının olağan olduğunu belirtmiştir (Adalet Partisi, 1967: 9).

TiP Genel Başkanı Mehmet Ali Aybar ve yedi arkadaşı, hükümetin anayasaya karşı zihniyet, tutum ve davranışlarının son zamanlarda yoğunlaştığına dair iddialar üzerine Millet Meclisi'nin 8 Şubat 1967 tarihli toplantısında bir gensoru önergesi (BCA, Dosya: D6, Fon Kodu: 030.01 Yer No: 54.327.5, 1- 2) ${ }^{5}$ vermişlerdir. Aybar ve arkadaşları, 1961 Anayasası'nın insan hak ve hürriyetlerine, milli dayanışmaya, sosyal adalete dayalı bir hukuk sistemini istediğini ifade etmişlerdir. Çok partili sosyal devlet düzeninin kuruluş yollarının, zorunlu olan dönüşüm ve reformların açıkça gösterildiğini belirten Aybar, sosyal devletin emekçi halk kitlelerinden yana olan ve onu savunan bir devlet olduğunun anayasada açıklandığını vurgulamıştır (MMTD, 8 Şubat 1967: 393- 394). Gensoru önergesinde AP'nin Demokrat Parti (DP)'nin mirasçısı olarak ortaya çıktığını ve 27 Mayıs'a karşı bir zihniyet, tutum ve davranışa girdiğini savunan Aybar, son zamanlarda Amerikan aleyhtarı akımlardan ve sosyalizmden hükümetin memnun olmadığını belirtmiştir. Aybar, Genelkurmay Başkanı tarafından verilen 21 Kasım 1966 tarihli emirnamenin AP ve Başbakan tarafından kabul edilmesinin Meclis'in ciddi bir anayasa meselesi ile karşı karşıya kaldığını iddia etmiştir. Aybar, Genelkurmay Başkanının beyanının anayasa ile bağdaşmadığını belirtmiş ve hükümetin bunu kabul ederek ağır bir sorumluluk içerisine girdiğini ifade etmiştir (MMTD, 8 Şubat 1967: 395). Aybar ve arkadaşları, emirnamede Amerikan aleyhtarlığının Batı aleyhtarlığı gibi gösterildiğini ve bunun hükümet tarafindan kabul edilmesinin anayasaya aykırı olduğunu savunmuşlar ve anayasanın 88 ve 89 . maddeleri gereğince hükümete gensoru açılmasını istenmişlerdir (MMTD, 8 Şubat 1967: 399; BCA, Dosya: D6, Fon Kodu: 030.01 Yer No: 54.327.5, 1617). Nihayet hükümete karşı verilen gensoru önergesinin gündeme alınıp alınmaması oylanmış ve gündeme alınmaması kararlaştırılmıştır (MMTD, 9 Şubat 1967: 468).

AP'nin tek başına iktidarda olduğu bu dönemde anayasa üzerine yapılan tartışmalar hız kesmemiştir. TíP Genel Başkanı Mehmet Ali Aybar, Demirel Hükümetinin 27 Mayıs Anayasasıyla intibaksızlık halinde olduğunu ve bu durumun AP'yi partizan bir yönetime ve faşizme sürüklediğini savunmuştur (Aybar, 1967: 22). Buna karşılık Süleyman Demirel, 1965-66 y1lı parlamentosunda anayasanın 88- 89. maddeleri kullanılarak AP'yi çalıştırmamanın amaçlandığını ve bunun AP'ye karşı tahammülsüzlükten kaynaklandığını, ağızlarıyla kuş tutsalar bile bu anlayışın değişmeyeceğini belirtmiştir (BCA, Dosya: C4, Fon Kodu: 030.01 Yer No: 47.280.5, 8). Türkiye'de anarşi ve terör, ağırlıklı bir görüşe göre komünizm ve bölücülükten diğer bir görüşe göre ise özgürlükçü bir yapıya sahip olan 1961 Anayasası'nın samimiyetle uygulanmamasından kaynaklanmaktadır (Burçak, 1988: 7). Özellikle 1965'ten sonra 1961 Anayasası için bol elbise, lüks anayasa tanımlamalarının yapıldığı düşünülürse, tartışmaların olağan olduğu söylenebilir (Soner, 2008: 29). Diğer taraftan bu dönemde AP'nin özellikle komünizm ve anayasa dışı faaliyetlerin engellenmesi konusunda 1961 Anayasası'nda bir değişiklik yapılmasını istediği anlaşılmaktadır (Tanör, 1986: 37).

AP'nin anayasada değişiklik istediği bu dönemde Bülent Ecevit, Başbakan Demirel'in anayasaya savaş açtı̆̆ını savunmuştur (Milliyet, 24 Ağustos 1967: 1). Başbakan Demirel, anayasa kuruluşları ile yasama organının kontrol edilmesi, murakabe edilmesinin doğru olmadığını, anayasaların kitab-1 semavi olmadığını ve değişebileceğini belirterek konuyla ilgili partisinin görüşünü de açıklamıştır (BCA, Dosya: C4, Fon Kodu: 030.01 Yer No: 47.280.5, 14). Demirel ayrıca, iktidarları döneminde 1961 Anayasası'nın getirdiği temel hak ve hürriyetlerin tümü ile kullanılmasının sağlandığını belirterek anayasa konusundaki hassasiyetlerini vurgulamıştır (Demirel, 1973: 311). Diğer

\footnotetext{
${ }^{4}$ İşçilerin bir kilo zeytine çalıştırıldığ 1 belirtilen açıklamada, bunun Türkiye'de değiştirilmesi gereken bir düzen olduğu savunulmuștur.

${ }^{5}$ Mehmet Ali Aybar ve yedi arkadaşının hükümet aleyhine gensoru açılmasına dair vermiş oldukları önerge, Millet Meclisi Başkanlığı'nca 8 Şubat 1967'de Başbakanlığa, 11 Şubat 1967'de ise Başbakanlık Müsteşarı Munis Faik Ozansoy tarafindan Devlet Bakanı Refet Sezgin'e gönderilmiştir.
} 
taraftan Güven Partisi Genel Başkanı Turhan Feyzioğlu da, siyasi hürriyetlerin bu hürriyetleri yok etmek için kullanılamayacağını belirtmiştir. Feyzioğlu hem TBMM içinde bulunmanın hem de bu çatıyı çökertmeye çalışmanın kabul edilemeyeceğini ifade etmiştir. Nihayet Feyzioğlu, hürriyetlerin kötüye kullanılmasını engellemek için anayasada önleyici bir hükmün bulunması gerektiğini savunmuştur (İpekçi, 1969: 124- 125, 225). Bütün bu değerlendirmeler, 1970 öncesinde anayasa değişikliği konusunun ciddi bir şekilde partilerin gündemine girdiğini göstermektedir.

\section{1961 Anayasası'nda Yapılan İlk Değişiklikler}

1961 Anayasası üzerine yapılan tartışmaların özellikle 1965 sonrasında yoğunlaştığını söylemiştik. Anayasa değişikliği konusundaki ilk fiili adım ise 1969 yılında atılmıştır. 27 Mayıs 1960 Darbesinden sonra yargılanan ve siyasi hakları ellerinden alınan Demokrat Partililerin siyasi haklarının iadesi konusu, 1961 Anayasası'nın değiştirilmesindeki ilk merhale olmuştur. 1969 seçimleri öncesinde hız kazanan anayasa değişikliği tartışmaları, partilerin siyasi birer manevrası olarak değerlendirilebilir. $\mathrm{Bu}$ çerçevede, siyasi hakların iadesi konusunda 14- 15 Mayıs 1969 tarihlerinde yapılan anayasada değişiklik teklifi Millet Meclisi'nde kabul edilmiştir (Adalet Partisi, 1970: 10). Millet Meclisi'nde kabul edilen anayasa değişiklik teklifi, nihayet Cumhuriyet Senatosu'nun gündemine getirilmiştir.

Türkiye'de yaşanan bu gelişmeler yabancı basın ve devlet organları tarafından yakından takip edilmiştir. Bu bağlamda, Amerikan Dışişleri Bakanlığı'na ait 19 Mayıs 1969 tarihli istihbarat bilgi notunda, eski DP'lilere siyasi hakların iadesine dair anayasa değişikliğinin Cumhuriyet Senatosu'ndan geçmesi halinde askerlerin müdahale edeceği, sivil kıyafetli istihbarat subayları tarafından senatörlere ulaştırıldığı belirtilmiştir (Foreıgn Relatıons of the Unıted States, Document 423, 2008: 1048). Diğer taraftan, Demokrat Partililerin siyasi haklarının iadesine dair anayasa değişikliği tartışmalarına ait haberler üzerine Ankara'da eylemlerin başladığını belirten Times, Türkiye'deki zayıf demokrasinin krizin eşiğinde olduğunu ifade etmiştir. Times, anayasa değişikliği gerçekleşirse askerin devirdiği siyasetçilerin tekrar sahneye çıkması durumunda askerin susup susmayacağını sormuştur. Subaylar arasında bir rahatsızlığın olduğunu belirten Times, General Fuat Doğu ile Başbakan Demirel'in görüşmesinin uğursuz bir durum olduğunu savunmuştur (The Times, May 20, 1969: 6). Bu bilgiler, yabancı devletlerin ve basının Türk iç politikası ile yakından ilgilendiklerini göstermektedir. Dönemin koşullarına bakıldığında, Silahlı Kuvvetlerin siyasi affın gerçekleşmesini istemediği anlaşılmaktadır. Sosyalist bir parti olan TİP de siyasi affın çıkarılması durumunda 27 Mayıs öncesine dönüleceğini savunmuştur (Kayalı, 2012: 144).

1969 seçimleri öncesinde Cumhuriyet Senatosu'na getirilen anayasa değişiklik teklifi, çeşitli nedenlerle askıya alınmıştır. Bu konuda, AP Senato Grubunda konuşan Başbakan Süleyman Demirel, günün icapları bakımından anayasa değişikliğinin komisyona iade edilmesini istemiş̧ir. Bu yapılmadığı takdirde kendisinin istifa edeceğini belirtmiştir. Nihayet Cumhuriyet Senatosu'nda yapılan oylama neticesinde, anayasa değişiklik teklifi AP'lilerin oylarıyla Anayasa ve Adalet Komisyonuna geri gönderilmiştir (Cumhuriyet, 22 Mayıs 1969: 1). DP'lilerin siyasi haklarının iadesi konusunu CHP de desteklemiş olmasına rağmen, menfi bir tavır takınılması nedeniyle değişiklik gerçekleşmemiştir (Kayal1, 2012: 144). Bu durum, anayasa değişikliğinin bir süre daha ertelendiğini göstermektedir.

Siyasi partiler arasında çeşitli tartışmalara yol açan anayasa değişikliği teklifi, sivil kanatta da yakından takip edilmiştir. Bu bağlamda, 27 Mayıs Milli Devrim Derneği tarafından düzenlenmiş olan toplantıda konuşan Anayasa Profesörü Hüseyin Nail Kubalı, anayasa tadilinin "karşı ihtilal" olacağını savunmuştur (Cumhuriyet, 29 Mayıs 1969: 1). 1969 yılı Mayıs ayında yoğun olarak gerçekleştirilmiş olan anayasa değişikliği tartışmaları, aynı yıl Ekim ayında da sıcaklığını korumuştur. Bu bağlamda Başbakan Demirel, 7 Ekim 1969'da Karadeniz'de yaptı̆̆ konuşmada, 1961 yılında Yassıada'da yargılananların siyasi haklarının tekrar verilmesi için anayasa değişikliğini destekleyeceğini söylemiştir. Reuters'a vermiş olduğu demeçte DP'liler için; "başından beri haksızlık yapıldı" dediği nakledilmiştir (The Times, Oct 8, 1969: 6). CHP ise, AP'nin DP'lilerin siyasal haklarının iadesi konusunda sürekli bir 
istismar yaptığını belirtmiştir. Bununla AP'nin kapatılan DP'nin oy mirasına sahip çıkmayı hedeflediği ve DP'lilerin siyasal haklarının iadesi konusunda da anayasa değişikliği gerektiği ve bunun için ise Meclis'te üçte iki çoğunluğu elde etme zorunluluğunun topluma anlatılmaya çalışıldığı savunulmuştur (Cumhuriyet Halk Partisi, 1970: 50- 51). Bu da CHP ile AP arasındaki siyasi rekabetin bu süreçte DP'lilerin siyasi affı konusunda yoğunlaştığını göstermektedir.

Seçim öncesinde yoğun olarak sürdürülmüş olan anayasa değişikliği tartışmaları, seçim sonrasına bırakılmıştır (Adalet Partisi, 1970: 11). 1969 seçimlerinden sonra 6 Kasım 1969'da kabul edilen ve 12 Kasım 1969 tarihli Resmi Gazete'de yayımlanan 1188 sayılı Kanunla 1961 Anayasası'nın milletvekili seçilme yeterliliğini belirleyen 68. maddesi değiştirilmiştir. Başlangıçta bu maddede sayılan suçlardan sonra "affa uğramış olsalar da" ifadesi yer alırken, yapılan değişiklikle bu ifade kaldırılmışır (Resmi Gazete, 12 Kasım 1969: 1; Eroğul, 1974: 149). 6 Kasım 1969'da ayrıca 1961 Anayasası'nın geçici 11. maddesi yürürlükten kaldırılmıştır. Bu madde ile anayasanın halkoyu ile kabulünden önce yüz kızartıcı olmayan bir suçtan dolayı hüküm giyen ve sonra affedilenlere ait seçilme yasağına dair kısıtlamaların kaldırıldığını belirtilen madde yürürlükten kaldırılmıştır (Resmi Gazete, 12 Kasım 1969: 1; Kili- Gözübüyük, 2006: 256; Eroğul, 1974: 149). Anayasanın 68. maddesinde yapılan değişiklik, geçici 11. maddenin değiştirilmesini zorunlu kılmıştır. Yapılan değişiklikle siyasi yasaklı DP'lilerin milletvekili seçilebilmelerinin önündeki engel kaldırılmıştır. Başbakan Süleyman Demirel de, 16. Basın Toplantısında siyasi hakların iadesi konusunda anayasanın 68. maddesinin tadili ve geçici 11. maddenin kaldırılmasının gerçekleştirildiğini basın mensupları ile paylaşmıştır (Adalet Partisi, 1970: 7). Ancak bu değişiklikler, TİP'in Anayasa Mahkemesi'ne açmış olduğu iptal davası üzerine Anayasa Mahkemesi tarafından değerlendirilmiş ve mahkemenin 16 Haziran 1970 tarihli kararı ile şekil yönünden iptal edilmiştir (Resmi Gazete, 7 Haziran 1971: 1- 8; Cumhuriyet, 17 Haziran 1970: 1) ${ }^{6}$. Böylece 1961 Anayasası'nda 1969 yılı Kasım ayında yapılan ilk değişiklikler uzun sürmemiş ve 1970 yılı Haziran ayında iptal edilmiştir (Adalet Partisi, 1970: 11; Kayal1, 2012: 144).

\section{1961 Anayasası’nda Yapılan İkinci ve Üçüncü Değişiklikler}

1961 Anayasası'nda kanunla yapılan ikinci ve üçüncü değişiklikler, 17 Nisan 1970 tarihinde gerçekleştirilmiştir. 1254 sayılı Kanunla 1961 Anayasası'nın 73. maddesi değiştirilmiş ve bir de geçici madde eklenmiştir. Anayasanın 73. maddesinde yapılan değişiklikle, Cumhuriyet Senatosu üyelerinin görev süreleri yeniden düzenlenmiştir. Yapılan değişiklikle, yenileme seçimlerinin Millet Meclisi seçimlerine rastlaması durumunda aynı zamanda yapılması, aksi takdirde genel seçimlerden iki yıl sonra genel seçimler için öngörülen ayda yapılması kararlaştırılmıştır. Senato seçimlerinin yenilenmesi veya geriye birakılmasına karar verilmesi durumunda, Cumhuriyet Senatosu seçimleri ile Millet Meclisi seçimlerinin aynı zamanda yapılmasına karar verilmiş olacağı belirtilmiştir. Geçici 11. madde ile de 7 Haziran 1970 tarihinde yapılması planlanan Cumhuriyet Senatosu yenileme seçimleri, 73. maddede yapılan değişiklik nedeniyle geriye bırakılmıştır (Resmi Gazete, 22 Nisan 1970: 3; Kili- Gözübüyük, 2006: 214- 215; Eroğul, 1974: 150). Yapılan bu değişikliklerle sik sık ve farklı zamanlarda yapılan seçimlerin engellenmesi hedeflenmiştir.

17 Nisan 1970 tarihinde 1255 sayılı Kanunla yapılan diğer bir değişiklik ise 1961 Anayasası'nın 131. maddesinde gerçekleştirilmiştir. Bu madde ile, ormanların ve orman köylüsünün korunması, ormanların geliştirilmesine yönelik bazı değişikliklere gidilmiştir. Bu değişiklikle özellikle ormanlar içinde veya yakınında oturan halkın kalkındırılması ve ormanın korunması bakımından devletle orman köylüsünün işbirliği yapması öngörülmüştür. Maddenin ilk haline göre fazladan bir paragraf eklenmiş, anayasanın yürürlüğe girdiği tarihten önce bilim ve fen açısından orman vasfinı yitirmiş toprakların

\footnotetext{
${ }^{6}$ Anayasa Mahkemesi’nin 16.6.1970 tarihli ve E.70/1 K.70/31 sayılı kararı ile değişiklik iptal edilmiştir. Mahkeme Heyeti 7 oya karşılık 8 oyla yani oy çokluğu ile, 6 Kasım 1969 tarihinde yapılan anayasa değişikliğinin Millet Meclisi'nde yapılan görüşmeler esnasında madde oylamalarında üçte iki çoğunluk aranmamasının kanunun şekil yönünden iptalini gerektirdiğini belirtilerek iptal etmiştir.
} 
hayvancılık veya tarımda kullanılması ile şehir- köy meskûn alanları dışındaki orman sınırlarında daraltmanın yapılamayacağı belirtilmiştir. Yapılan değişiklikle "orman suçları için genel af çıkarılamaz" hükmü kaldırılmış ve bir yumuşama eğilimi gösterilmiştir (Resmi Gazete, 22 Nisan 1970: 3- 4; KiliGözübüyük, 2006: 237- 238; Eroğul, 1974: 151- 152). İkinci ve üçüncü değişikliklerden sonra ilk değişikliğin Anayasa Mahkemesi tarafından iptal edilmesi nedeniyle, değişiklik sayısı 1970 yılında iki ile sınırlı kalmıştır.

1970 dönemecinde Türkiye'nin iç politikada karşılaşmış olduğu sorunlar, anayasa ve temel haklarla doğrudan bağlantılı olmuştur. Cumhuriyet Senatosu Eskişehir Üyesi Ömer Ucuzal, 1 Haziran 1970 tarihinde Ankara'da yapılan "Anayasaya sayg1 ve üniversite özerkliğini koruma” yürüyüşü hakkında Cumhuriyet Senatosu'nda bir konuşma yapmıştır. Bu yürüyüşe çeşitli üniversitelerden öğrenciler yanında üniversite rektörlerinin, dekanlarının ve profesörlerinin de katıldığını belirtmiştir. Ucuzal, gösterinin anayasal bir hak olduğunu belirtmiş, ancak yürüyüş sırasında taşınan dövizlere dikkat çekmiştir. Ucuzal, "Kahrolsun Amerika", "Kanlı İktidar", "Milli Sanayi", "Milli Demokrasi" gibi dövizlerin yürüyüşle alakasız olduğunu belirtmiş ve yürüyüşü eleştirmiştir (CSTD, 4 Haziran 1970: 183). Diğer taraftan 15- 16 Haziran 1970 işçi olaylarında üç ay süreyle sıkıyönetim ilan edilmiştir. Bu dönemde anayasal hakların ve hürriyetlerin kullanılmasında ciddi bir kısıtlama olmamıştır (Arcayürek, 1992: 251). Bütün bunlar, gücünü anayasanın özgürlükçü yapısından alan bazı grupların bu süreçte farklı amaçlara yöneldiklerini göstermektedir.

\section{12 Mart Muhtırasından Sonra Anayasa Değişikliğine Giden Süreç}

Türkiye'yi 12 Mart sürecine götüren en önemli konu, toplum içerisinde yaygın hale gelmiş olan anarşi ve kargaşa olmuştur. 12 Mart 1971 Muhtırasında anarşi ve kardeş kavgasının sorumluluğu hükümet ve parlamentoya yüklenmiş, anayasanın öngördüğü reformların gerçekleştirilemediği belirtilmiştir. Anarşinin ortadan kaldırılması ve anayasanın öngörmüş olduğu reformları Atatürkçü bir görüşle ele alacak inandırıcı bir hükümetin kurulması gerektiği belirtilmiştir (CSTD, 13 Mart 1971: 373; MMTD, 12 Mart 1971: 236). Muhtırada anayasa değişikliğine işaret edilmemiş olmakla birlikte, hükümetlerin karşılaşmış oldukları sorunların çözümü konusunda sıkça anayasa değişikliğine müracaat ettikleri bilinmektedir (Özdemir, 2011: 265). Diğer taraftan ülkede son yıllarda yaşanmış olan toplumsal kargaşanın en önemli nedenlerinden birisinin mevcut anayasanın özgürlükçü yapısından kaynaklandığına dair yaygın bir düşünce bulunmaktadır. Nihayet bu düşüncenin, anayasa değişikliğini hızlandırdığı anlaşılmaktadır.

12 Mart Muhtırasında anayasa değişikliği öngörülmemiş olmakla birlikte, devlet otoritesini güçlendirmek amacıyla anayasal bir değişikliğin yapılacağı anlaşılmaktadır (Tanör, 1986: 42- 43). Konuyla ilgili olarak dönemin Genelkurmay Başkanı Orgeneral Memduh Tağmaç, 1961 Anayasası'nın ülkenin sosyo- ekonomik gelişmesine bol geldiğini söylemiştir (Çavdar, 1996: 211). Türk Silahlı Kuvvetleri, bu süreçte Cumhurbaşkanı Cevdet Sunay'a da ayrı bir muhtıra vermiştir. Bu muhtırada özellikle 1961 Anayasası'nın "temel haklar ve ödevler" kısmını düzenleyen 10- 34. maddeleri arasındaki bir kısım maddelerin değiştirilmesi gerektiğinden bahsedilmiştir (Yazıcı, 1997: 116- 119). 12 Mart sonrasında düşünülen anayasa değişikliğinin, Genelkurmay Adli Müşavirliğinde kaleme alındığı anlaşılmaktadır. Bu da askerlerin anayasal düzenlemelere ait gelişmelerden uzak kalmadıklarını göstermektedir (Tanör, 1986: 50- 51; Yazıcı, 1997: 119). Özetle 12 Mart Muhtırasından sonra askerler, anayasa değişikliğini mevcut hükümete bırakmamışlar, değişikliklerin bizzat içerisinde yer almışlardır.

12 Mart Muhtırasından sonra Silahlı Kuvvetlere mensup subaylar, 1961 Anayasası'nın bazı maddelerini fazlasıyla liberal bularak değiştirilmesini isterken (Cook, 2008: 78), partiler üstü hükümetin Başbakanı Nihat Erim de, 1961 Anayasası'nın oldukça liberal bir anayasa olduğunu ve Türkiye için bu anayasanın lüks olduğunu vurgulamıştır (Gevgilili, 1987: 527). Burada özellikle 1961 Anayasası'nın lüks olduğu düşünülen kısımlarının hak ve özgürlükler konusunda olduğu, bunların belli bir sınırlamaya tabi tutulmasının amaçlandığı anlaşılmaktadır (Ahmad, 2010: 363). Anayasanın değiştirilmesine dair bir 
başka iddiayı da Sadi Koçaş ortaya atmıştır. Koçaş, 12 Mart'tan sonra anayasa değişikliği teklifini ilk olarak MITT Müsteşarının ağzından duyduğunu belirtmiş ve bu teklifin 5- 6 yıldır hükümetlerin söyledikleri teklifin dahi üzerinde olduğunu ifade etmiştir (Koçaş, 1978: 154- 155). Bütün bunlar, 12 Mart Muhtırasından sonra anayasa değişikliği konusunda ortak bir görüşün egemen olduğunu göstermektedir.

Başbakan Nihat Erim, partilerden anayasada beğenmedikleri maddeleri yazmalarını istemiştir. Demokratik Parti, konuyla ilgili olarak parti temsilcilerinden oluşan bir komisyonun kurulmasını talep etmiştir. Bu bağlamda her siyasi parti, görüşlerini hükümete bildirmiştir (Bozbeyli, 2009: 342- 343). Yapılacak anayasa değişikliği konusunda Başbakan Erim, toplumun çeşitli kesimleri ile de görüşmeler gerçekleştirmiştir. Bu kapsamda, 8 Mayıs 1971'de Prof. Mümtaz Soysal, Prof. Bahri Savc1, Prof. Münci Kapani gibi Ankara'daki hukukçularla bir toplantı yapmıştır. Bu hukukçulara göre terör ve anarşi, anayasa değiş̧ikliği yapılmadan da engellenebilirdi. Aynı gün Yargıtay 1. Ceza Dairesi, kamu düzeni ve ulusal güvenlik için temel hak ve hürriyetlerin sınırlandırılabileceğine karar vermiştir (Gevgilili, 1987: 528). Erim, bu konuyu İstanbul'dan Prof. Hüseyin Nail Kubalı ve Prof. Tarık Zafer Tunaya ile de görüşmüştür. Tunaya reformların anayasa değişikliği yapılmadan da yapılabileceğini savunurken, Kubalı anayasa değişikliğini savunmuştur (Cumhuriyet, 10 Mayıs 1971: 1; Cumhuriyet, 13 Mayıs 1971: 1; Gevgilili, 1987: 528- 529).

Anayasa değişikliği tartışmalarının yaşandığı bir süreçte Fransız Hukukçu Prof. Duverger'in Türkiye'ye davet edilmesi eleştirilmiştir. Eleştirinin en temel nedeni ise, ülkede yetişmiş birçok hukukçunun olmasına rağmen bir yabancının davet edilmiş olmasıdır (Selçuk, 27 Nisan 1971: 2). Yapılacak anayasa değişikliğinin sınırları da bu dönemde basında tartışılmaya başlamıştır. Anayasada yapılacak değişikliklerle hükümete kanun hükmünde kararname çıarma yetkisinin verilmesi ve hükümetin icra gücünün daha etkili hale getirilmesinin hedeflendiği vurgulanmıştır (Hürriyet, 1 Mayıs 1971: 1). Bütün bu tartışmalar, son yıllarda yaşanan sorunların ortadan kaldırılmasının arzulandığına bir işaret sayılabilir.

AP'nin aksine Tï, 11 Mayıs 1971'de yayınlamış olduğu bildiride anayasa değişikliğine karşı çıkmıştır (Cumhuriyet, 12 Mayıs 1971: 1). 12 Mart Muhtırasından sonra kurulan partiler üstü hükümette görev alan Sadi Koçaş da, olası anayasa değişikliği konusundaki ısrarların devam etmesi durumunda istifa etmeyi düşündüğünü İsmet İnönü’ye söylemiş ve izin istemiştir. İsmet İnönü ise, hiçbir şartta istifa etmemesi gerektiğini belirtmiş ve kötü niyetli kişilerin kenarda beklediğini belirterek görevden asla çekilmemesini ögütlemiştir (Koçaş, 1978: 161). Koçaş, anayasada değişiklik isteyenlere karşı CHP'nin desteğini aldıklarını ve değişiklik isteyen AP ve GP'nin karşısına dikilebileceklerini Başbakan Nihat Erim'e anlatmıştır. Anılarında Koçaş, Başbakan Erim’in de başlangıçta anayasa değişikliğine karşı çıktığını ancak, sonradan değişikliği kabul ettiğini belirtmiştir. Koçaş, bu konuda Genelkurmay Başkanı Memduh Tağmaç'ın Türk Silahlı Kuvvetleri'nin anayasa değişikliği istediğine dair sözlerinin etkili olduğunu ve Erim'in de ordu ile karşı karşıya gelmemek için anayasa değişikliğini kabul ettiğini belirtmiştir (Koçaş, 1978: 164- 171). Anlaşılan o ki Koçaş, anayasanın değiştirilmemesi konusunda hükümet üyesi olarak büyük gayret göstermiş, ancak başarılı olamamıştır.

Demokratik Parti Genel Başkanı Ferruh Bozbeyli ise, 25 Mayıs 1971'de Anadolu Ajansı'na vermiş olduğu demeçte, 1961 Anayasası'nda; hürriyetçi demokratik nizamı değiştirmeye ve tahribe yönelik sapık ideolojilere karşı kesin tedbirler alınmasını ve gerekli değişikliklerin yapılmasını istemiştir (Demokratik Parti, 1971: 206). Diğer taraftan Demokratik Parti'ye geçen Çanakkale Senatörü Ziya Termen, 5 Haziran 1971'de bir basın toplantısı yapmıştır. Termen, 12 Mart Muhtırasından sonra Türkiye'nin kendisini kurtaran devlet niteliğine kavuştuğunu belirtmiştir. Termen, muhtıranın ikinci bir Menderes faciasından öte, devleti sıhhate ve milleti emniyete kavuşturan tarihi ve yapıcı bir hadise olduğunu savunmuştur (Demokratik Parti, 1971: 209). Buradan Demokratik Parti’nin 12 Mart sonrasında yapılacak anayasa değişikliklerini destekleyeceğini söyleyebiliriz. 


\section{1961 Anayasası’nda Yapılan Dördünciü Değişiklik}

12 Mart'tan sonra ilk anayasa değişikliği, 30 Haziran 1971'de 1421 sayılı Kanunla yapılmıştır (Tanör, 1986: 39; Yazıc1, 1997: 118). Bu Kanun 2 Temmuz 1971 tarihli Resmi Gazete'de yayımlanmıştır. Bu Kanunla, 1961 Anayasası'nın 56 ve 82. maddeleri değiş̧ikliğe uğramıştır (Resmi Gazete, 2 Temmuz 1971: 1). Anayasanın 56. maddesine eklenen bir paragraf ile, siyasi partilere devlet tarafından yardım yapılmasının önü açılmıştır. Buna göre, son milletvekili genel seçimlerinde geçerli oyların en az yüzde beşini alan veya Millet Meclisi'nde grup teşkil edebilecek sayıda milletvekilliği kazanmış bulunan siyasi partilere yapılacak yardımın kanunla düzenleneceği belirtilmiştir (KiliGözübüyük, 2006: 208; Resmi Gazete, 2 Temmuz 1971: 1). Yine 82. maddede yapılan değişiklikle parlamenterlere yapılacak her türlü zam ve tazminatın ilk genel seçimlerden sonra uygulanmasını düzenleyen paragrafi kaldırılmış ve böylece hemen uygulanması usulü getirilmiştir. Ayrıca, TBMM üyelerine aylık yapılacak ödeneğin en yüksek devlet memurunun aldığı miktardan fazla olamayacağ1, yolluğun da ödeneğin yarısını geçemeyeceği belirtilmiştir (Resmi Gazete, 2 Temmuz 1971: 1; Eroğul, 1974: 153). Siyasi partilere yapılacak yardım konusu anayasaya eklenerek, şartları tutan partilerin rahatlaması sağlanmıştır. Diğer taraftan yapılan düzenleme ile TBMM üyelerinin mali hakları düzenlenmiştir.

\section{6. $\quad 1961$ Anayasası'nda Yapılan Beşinci Değişiklik}

12 Mart Muhtırasının uygulanması sürecindeki en büyük anayasa değişikliği, 1971 yılı Eylül ayında gerçekleştirilmiştir (Kili, 2001: 365). Burada 1961 Anayasası'nın 35 maddesi değiştirilirken, anayasaya 9 da geçici madde eklenmiştir (Eroğul, 1974: 154; Demirel, 1973: 351; Resmi Gazete, 22 Eylül 1971: 1). 20 Eylül 1971 tarihinde kabul edilen 1488 sayılı Kanunla yapılan değişiklikler, 22 Eylül 1971 tarihli Resmi Gazete' de yayımlanmıştır (Resmi Gazete, 22 Eylül 1971: 1; Tanör, 1986: 39; Yazıcı, 1997: 119). Anayasa değiş̧ikliği konusunda hem Millet Meclisi'nde hem de Cumhuriyet Senatosu'nda görüşmeler gerçekleştirilmiştir. Bu kapsamda Millet Meclisi üyelerinden 430'u 1961 Anayasası'nın bazı maddelerinin değiştirilmesine ve bazı geçici maddelerin eklenmesine dair teklifi, 28 Ağustos 1971'de Millet Meclisi'nde görüşmüştür. Bu görüşmelerde 22, 26, 29, 30, 32, 38, 46, 60, 61, 64, 89, 110, 111, 114 ve 119. maddeler kabul edilmiştir (MMTD, 28 Ağustos 1971: 323-459).

1971 yılında düşünülen değişiklik; "Türkiye Cumhuriyeti Anayasasının bazı maddelerinin değiştirilmesi ve geçici maddeler eklenmesi hakkında Anayasa değişikliği teklifi”" adıyla görüşülmüştür. Bu değişiklik teklifi 35 ana maddeden oluşmuştur (CSTD, 12 Eylül 1971: 310). Anayasada yapılacak olan bu beşinci değişiklik teklifi ile temel haklar ve ödevler bölümünde yer alan 11, 15, 19, 22, 26, 29, 30, 32; Sosyal ve iktisadi haklar ile siyasi haklarla ilgili üçüncü ve dördüncü bölümün 38, 46, 60, 61; Cumhuriyetin temel kuruluşunu kapsayan üçüncü kısmında yer alan yasamaya ait birinci bölümün 64, 89, 110, 111; İdare bölümündeki 114, 119, 120, 121, 124; İktisadi ve mali bölümde bulunan 127; Yarg1 organına ilişskin on yedinci bölümün 134, 137, 138; Yüksek mahkemeler bölümünün 139, 140, 141; Yüksek Hakimler Kurulu ile ilgili 143, 144; Anayasa Mahkemesiyle ilgili 145, 147, 149, 151, 152. maddelerinin değiştirilmesi ve 9 (dokuz) da geçici madde eklenmesi hedeflenmiştir (CSTD, 12 Eylül 1971: 232).

AP Genel Başkanı Süleyman Demirel, 1961 Anayasası'nda yapılması planlanan değişiklikler münasebetiyle 28 Ağustos 1971'de Millet Meclisi'nde bir konuşma yapmıştır. Konuşmasında hükümet tarafından getirilen teklifin siyasi partilerce değerlendirildiğini ve ortak bir taslak oluşturulduğunu ifade etmiştir (Adalet Partisi, 1972: 33). Anayasanın geçici maddeler dışında 35 esas maddesini değiştirmenin öngörüldügünü belirten Demirel, şunları ifade etmiştir: "Bu maddelerden ikisi sosyal ve ekonomik hususlarla ilgilidir. Diğer 33 madde anayasanın hürriyetçi temelini güçlendirmekte, kavram karışıklıklarını önlemekte, organlar arasında yetki, görev ve sorumluluk dengesi kurmakta ve icrayı müessir hale getirme gayesini gütmektedir. Anayasada yer alan hak ve hürriyetlerden hiçbirisinin Anayasa ile kurulan ve milli hâkimiyete dayanan demokratik rejimi tahrip istikametinde 
kullanılamayacağının bütün unsurları ile kesin ve açık olarak yasaklanmış olması her türlü Anayasa dışı cereyanlara karş1 rejime yeni bir savunma gücü vermektedir (Adalet Partisi, 1972: 36).” Demirel, üniversitelerle ilgili getirilen teklifte hem üniversite özerkliğinin her türlü müdahaleye ve anarşiye karş1 korunacağını hem de üniversitelerin yurt sathına yayılmasına imkan tanınacağını belirtmiştir. Demirel, TRT ile ilgili yapılan değişiklikte de TRT'nin özerkliğinin kaldırıldığını, tarafsız kamu tüzel kişiliğine büründüğünü belirtmiştir. Böylece devlet radyosu ve televizyonu devletin emrine girmiştir (Adalet Partisi, 1972: 39- 40).

Süleyman Demirel, memlekette bir kısım gençlerin anarşi hareketlerine karıştığını ve bunların amacının cumhuriyeti yıkmak olduğunu belirtmiştir. Anayasa değişikliğiyle ilgili konuşmasına devamla şunları söylemiş̦tir: “Türkiye'de anarşi hareketlerini yaratan, gençler denilen örgütlerde yer alan kişiler ne şehir çetesidir ne şehir eşkıyasıdır. Doğrudan doğruya dünyanın çeşitli memleketlerinde görüldüğü gibi bir memleketi içinden fethetmeğe memur edilmiş komünist çeteleridir (Adalet Partisi, 1972: 41).” Çeşitli konularda hazırlanmış kanun tasarılarının desteklendiğini belirten Demirel, anayasanın 35 maddesinin değiştirilmesinde de yardımcı olduklarını vurgulamıştır (Demirel, 1977: 123; Ateş, 2007: 70). Özetle Demirel, memleketin içinde bulunduğu buhranı aşmak için Erim Hükümetine gerekli desteği sağladıklarını ifade etmiştir (Adalet Partisi, 1972: 59). Demirel'in yapmış olduğu konuşmadan hareketle, iktidarları döneminde yaşanan önemli bir takım sorunların kişi hak ve özgürlüklerinin suiistimal edilmesinden kaynaklandığı söylenebilir.

Anayasa değişikliklerinin Millet Meclisi'nde yapılan görüşmelerinde İstanbul Milletvekili Mehmet Ali Aybar (Ahmad, 2010:365) ${ }^{7}$ da, 5 Eylül 1971'de bir önerge vererek, birinci görüşmelerde kabul edilen anayasanın 11. maddesinin değiştirilmesini talep etmiştir. Ona göre demokratik anayasalarda haklar ve hürriyetler anayasa metninde sinırlandırılmamaktadır. Aybar, bu hakların anayasa içerisinde sınırlandırıldığı zaman, bunları kötüye kullanmayanlar için de sınırlanmış olacağını belirtmiştir. Nihayet, Aybar'ın değişiklik önergesi kabul edilmemiştir (MMTD, 5 Eylül 1971: 706- 709). Aybar'ın önergesi ve konuşmasından sonra söz alan Anayasa Komisyonu Başkanı Cevdet Akçalı ise, 1961 Anayasası'nda sosyalizm kelimesinin geçmediğini belirtmiş, Enver Ziya Karal ve Muammer Aksoy'un açıklamaları çerçevesinde cevaplamıştır. Bu bağlamda Akçalı, 1961 Anayasası'nda herhangi bir doktrinin olmadığını ve komünistliğin tatbik edilemeyeceğini vurgulamıştır (MMTD, 5 Eylül 1971: 708- 709). Bu değerlendirmeler, 1961 Anayasası'nın hak ve özgürlüklere ait içeriği ile kavramlar üzerinden ideoloji yorumlamalarının yapıldığını göstermektedir.

Millet Meclisi'nde 1961 Anayasası'nın bazı maddelerinin değiştirilmesi ve anayasaya geçici maddeler eklenmesine dair ikinci kez yapılan görüşmeler sonunda 5 Eylül 1971'de teklifin tümü üzerinde yapılan oylamaya 360 kişi katılmış, katılanların 358'i değişiklikleri kabul ederken 2'si reddetmiştir. Böylece, yapılan değişiklikler Millet Meclisi'nde kabul edilmiştir (MMTD, 5 Eylül 1971: 1004). Nihat Erim Hükümetinin getirmiş olduğu anayasa değişiklik tasarısı, 12 Eylül 1971'de Cumhuriyet Senatosu'nda görüşülmeye başlamıştır. CHP adına bir konuşma yapan Hıfzı Oğuz Bekata, anayasanın hürriyetçi yapısının ve temel ilkelerinin bütünüyle korunarak hazırlanmasından duyduğu memnuniyeti dile getirmiştir. Bekata, anayasa değişikliğinde üç yönün olduğunu belirtmiştir. 1961 Anayasası'nın geniş hürriyetler getirdiğini ve bu hürriyetlerin özünün korunması gerektiğini, ancak hürriyet ortamından yararlanılarak milli birlik ve beraberliğin bozulmasının ve demokrasinin kötüye kullanılmasının önlenmesi gerektiğini belirtmiştir. Ayrıca, Türk Devleti’nin vatanı ve milleti üzerine sadece düşmanlarını sevindirecek ideolojik ve bölücü faaliyetlerin önüne geçilmesinin hedeflendiğini belirtmiştir. Son olarak da Türkiye'nin hızla kalkınmasını gerektiren temel reformların sosyal adalete uygun olarak gerçekleştirilmesi gerektiğini vurgulayan Bekata, anayasa değişikliği konusunda temel alınan bu özelliklerin CHP tarafından desteklendiğini belirtmiştir (CSTD, 12 Eylül 1971: 227, 292).

\footnotetext{
${ }^{7}$ Anayasa değişikliğine TíP’in kapatılmış olması nedeniyle ciddi bir protesto gelmemiştir. Sadece Mehmet Ali Aybar, önerilen değişikliklerin amacının sosyalizmi yasaklamak olduğunu ve çağdaş demokratik anlayışla bağdaşmayacağını belirtmiştir.
} 
Anayasa değişikliği konusunda Milli Güven Partisi adına Sedat Çumralı da bir konuşma yapmıştır. Çumralı, 1961 Anayasası'nın komünizmi, faşizmi, teokratik devleti ve her türlü diktacı hevesleri kesinlikle önlemekte ise de anayasadaki hürriyet rejimi ile hak ve hürriyetlerin ülkeyi anarşi ortamına doğru sürüklemek için maksatlı olarak kullanılmasının anayasadaki hürriyeti düzenleyen bazı hükümlerin aydınlatıcı hale getirilmesinin zorunluluk haline geldiğini belirtmiştir. Çumralı, 1961 Anayasası'nda yapılacak 35 maddelik değişikliğin, zamanın şartlarına göre 1948 tarihli İnsan Hakları Evrensel Beyannamesi'nin 29 ve 30. maddeleri ile Avrupa İnsan Hakları Antlaşması'nın 17. maddesine uygun olarak hazırlandığını vurgulamıştır (CSTD, 12 Eylül 1971: 233).

Adalet Partisi Grubu adına Ahmet Nusret Tuna da bir konuşma yapmıştır. Anayasa değişikliğinin parlamentoda bulunan siyasi partilerin ortak ürünü olduğunu belirten Tuna, Adalet Partisi için anayasa değişikliğinin yeni olmadığını ve 1969 seçimlerine gidilirken hangi konularda nasıl değişiklikler yapılmasının düşünüldüğünün açıklandığını belirtmiştir (CSTD, 12 Eylül 1971: 251 - 252). Tuna, 1968 yılı Haziran ayından sonra dünyada bir merkezden yönetilen tahriklerle komünistlerin ortalığı karıştırdıklarını belirtmiş, Türkiye'nin fakir bir ülke olarak sınırlı olanaklar içinde sosyal ve ekonomik önlemler almaya çalıştığını belirtmiştir (CSTD, 12 Eylül 1971: 256). Kurucu Meclis olarak görev yapıldığını belirten Tuna, farklı siyasi düşünceleri parlamento dışında bırakarak, anayasayı geldiği merhaleden geriye götürmeyecek şekilde bir gelişmenin sağlanmasını önermiştir (CSTD, 12 Eylül 1971: 263).

Milli Birlik Grubu adına da Ahmet Yıldız, anayasa değişikliği üzerine bir konuşma yapmıştır. 1961 Anayasası'nın tüm geçmiş devrimcilerin özlemlerini gerçekleştiren bir anıtsal belge olduğunu savunan Yıldız, 1961 Anayasası'nı sadece bir tepki anayasası olarak değerlendirmenin mümkün olmadığını, bilakis kuşaklar boyunca sürüp gelen çabaların bir yapıtı olduğunu vurgulamıştır (CSTD, 12 Eylül 1971: 234). Yıldız, 27 Mayıs Anayasasının klasik devlet düzeninden çağın sosyal devlet düzenine geçişi hedefleyen dinamik bir belge olduğunu belirtmiş, Türk düşün gücünün üstün bir yapıtı olduğunu vurgulamıştır (CSTD, 12 Eylül 1971: 235). Başbakan Erim’in daha önce sorulmuş bir soruya; anayasa değişikliği düşünmediklerini belirttiği yönündeki ifadelerini hatırlatan Yıldız, anayasa değişikliğine karşı olmalarının hükümete karşı olmak şeklinde anlaşılmaması gerektiğini belirtmiştir. Yıldız ayrıca, 1961 Anayasası'nı çok ileri bulma ve toplumu böyle ileri bir anayasaya yeterli görmemenin haksız ve gurur incitici bir durum olduğunu ifade etmiştir (CSTD, 12 Eylül 1971: 236).

Tabii Senatör Ekrem Acuner de anayasa değişikliği konusunda söz almıştır. 12 Mart'ta anayasanın öngördüğü reformları yapmayanların suçlandığını belirten Acuner, şimdi de bizzat anayasanın suçlandığını belirtmiştir. Acuner, 1961 Anayasası'nın mimarı olan Türk Silahlı Kuvvetlerinin yine kendi eliyle anayasa değişikliğine gitmesinin tuhaf olduğunu vurgulamıştır (CSTD, 12 Eylül 1971: 271). Kocaeli Senatörü Fatma Hikmet İşmen de, 1971'de yapılan anayasa değişikliğinin başlı başına bir değişiklik olduğunu ve 1961 Anayasası'nın felsefesini ortadan kaldırdığını belirtmiş ve bunun bir değişiklik değil “1971 Anayasası” olduğunu vurgulamıştır (CSTD, 12 Eylül 1971: 292).

1971 y1lında anayasa değişikliğinin birinci müzakeresi ve oylaması Cumhuriyet Senatosu'nda 14 Eylül 1971'de tamamlanmıştır (CSTD, 14 Eylül 1971: 518). Türkiye Cumhuriyeti Anayasasının bazı maddelerinin değiştirilmesi ve geçici maddeler eklenmesi hakkında anayasa değişikliği teklifinin tümü üzerine yapılan ikinci müzakerelerden sonra 20 Eylül 1971'de oylama yapılmış ve 148 üyenin katıldığ oylamada 135 kabul oyu, 12 ret oyu kullanılırken 1 kişi de çekimser kalmıştır (CSTD, 20 Eylül 1971: 743; Gevgilili, 1987: 533). Millet Meclisi anayasa değişikliklerini 5 Eylül 1971'de kabul ederken, Cumhuriyet Senatosu ise 20 Eylül 1971'de kabul etmiştir (Ahmad, 2010: 365). 1961 Anayasası'nı hazırlatan askerler, 12 Mart Muhtırasından sonra anayasa değişikliği istemişler ve anayasa değiş̧ikliklerinde önemli bir rol üstlenmişlerdir. $\mathrm{Bu}$ arada Silahlı Kuvvetlerin istemiş olduğu değişikliklerle AP'nin istemiş olduğu değişiklikler arasında bir paralellik olduğu gözlenmektedir. CHP'nin ise yapılan değişiklikleri istememekle birlikte, muhtıranın üçüncü maddesindeki darbe tehdidi nedeniyle olumlu oy kullandığı anlaşılmaktadır (Yazıcı, 1997: 118; Cook, 2008: 30). 
Kontenjan Senatörü Kasım Gülek, yapılan anayasa değişikliği ile birlikte hükümetin ivedi bir şekilde iktisadi güçlüklere el atması gerektiğini belirtmiştir (CSTD, 21 Eylül 1971: 747). Buna karşılık Başbakan Yardımcısı Attila Karaosmanoğlu, hükümetin ilk günden itibaren iktisadi güçlüklerin halledilmesiyle ilgili çalıştı̆̆ını ve devamlı tedbirler aldığını belirtmiş ve varsa istenen başka tedbirler bunların bildirilmesini üyelerden istemiştir (CSTD, 21 Eylül 1971: 748). Sakarya Üyesi Mustafa Tığlı ise sosyalizm konusunu gündeme taşımıştır. Tığlı, sosyalizmin kişi hak ve hürriyetlerini büsbütün yok eden, kişiyi devletin kölesi haline getiren bir sistem olduğunu belirtmiş, Türkiye'nin beşeri ve sosyal geleneğine bu sistemin uygun olmadığını ifade etmiştir. Tığl1, sosyal adalet hukukunun zaruri kıldığı her türlü sosyal tedbirin sosyalizme ve komünizme karşı bir tedbir olduğunu vurgulamıştır (CSTD, 28 Eylül 1971: 832).

1971 yılında anayasada yapılan beşinci değişiklik kapsamında, konu içeriklerine göre değişiklikleri değerlendirmenin faydalı olacağını düşünmekteyiz. Bu bağlamda konuya anayasanın "temel haklar ve ödevler" bölümünde yapılan değişiklikle başlamak gerekmektedir. 1961 Anayasası'nın 11. maddesinde (CSTD, 20 Eylül 1971: 582- 583) ${ }^{8}$ yapılan değişiklik şu şekildedir: "Temel hak ve hürriyetler, Devletin ülkesi ve milletiyle bütünlüğünün, Cumhuriyetin, millî güvenliğin, kamu düzeninin, kamu yararının, genel ahlâkın ve genel sağlığın korunması amacı ile veya Anayasanın diğer maddelerinde gösterilen özel sebeplerle, Anayasanın sözüne ve ruhuna uygun olarak, ancak kanunla sinırlanabilir. Kanun, temel hak ve hürriyetlerin özüne dokunamaz. Bu Anayasada yer alan hak ve hürriyetlerden hiçbirisi, insan hak ve hürriyetlerini veya Türk Devletinin ülkesi ve milletiyle bölünmez bütünlüğ̈̈n̈̈ veya dil, ırk, sınıf, din ve mezhep ayırımına dayanarak, nitelikleri Anayasada belirtilen Cumhuriyeti ortadan kaldırmak kasdı ile kullanılamaz. Bu hükümlere aykırı eylem ve davranışların cezası kanunda gösterilir (CSTD, 13 Eylül 1971: 335).” Anayasada yapılan bu değişiklikle hak ve hürriyetlerin hiçbirisinin Cumhuriyeti ortadan kaldırma kastı ile kullanılamayacağı belirtilmiştir (Tanör, 1986: 58). Böylece, milli güvenliğin ve kamu düzeninin korunması konusunda hürriyetlerin kontrol altında tutulabileceği vurgulanmıştır.

1961 Anayasası'nın temel haklar bölümünde "özel hayatın gizliliği” başlıklı 15. maddesi de değişikliğe uğramıştır. Kamu düzeni yanında milli güvenlik ifadesi de maddeye girmiş ve kanunla yetkili k1lınan merciin emri olmadıkça, gecikmede sakınca bulunan hallerde de kimsenin üstünün, özel eşyasının ve kâğıtlarının aranamayacağı belirtilmiştir (Resmi Gazete, 22 Eylül 1971: 1; KiliGözübüyük, 2006: 195). Vicdan ve din hürriyeti başlığını taşıyan 19. madde de değişikliğe uğramıştır. Kişiler ve dernekler kavramı yerine gerçek ve tüzel kişiler kavramı anayasaya girmiş, dini ve din duygularını istismar eden gerçek ve tüzel kişilere kanunun gösterdiği hükümlerin uygulanacağı belirtilmiştir. Burada gerçek ve tüzel kişiler kavramı tercih edildiği için derneklerin yetkili mahkemece kapatılacağı ifadesi maddeden çıkarılmıştır (Kili- Gözübüyük, 2006: 196- 197). Bu maddede yapılan değişiklikle, kanunun gücüne işaret edildiği görülmektedir.

1961 Anayasası'nda yapılan bir diğer değişiklik ise “basın hürriyetini” açıklayan 22. maddede gerçekleştirilmiştir. Bu maddede yapılan değişiklikle milli güvenliğin, kamu düzeninin ve genel ahlakın korunması bakımından gecikmesinde sakınca bulunulan hallerde hakimin kararı beklenmeden gazete ve dergilerin kanunun yetkili kıldığı mercilerce toplatılabileceği belirtilmiştir. Ancak yetkili merciin bu kararı 24 saat içerisinde mahkemeye bildirmesi ve mahkemenin de en geç üç gün içerisinde onaylamaması durumunda toplatma kararının hükümsüz kalacağı vurgulanmıştır. Gazete ve dergilerin hangi durumlarda mahkeme kararıyla kapatılacağı açık bir şekilde sıralanmıştır. Burada özellikle milli

\footnotetext{
81961 Anayasası'nın 20 Eylül 1971'de Cumhuriyet Senatosu'nda yapılan görüşmelerinde, anayasanın 11. maddesinin değiştirilmemesi gerektiğini savunan Diyarbakır Senatörü Selahattin Cizrelioğlu, bir önerge vermiştir. Cizrelioğlu, anayasa değişikliklerinin ileriye doğru yapılması gerektiğini belirtmiş, temel hak ve hürriyetlerin anayasanın sözüne ve ruhuna uygun olarak sınırlanabileceği belirtilmiş olmasına rağmen, bazı sebepler ileri sürülerek temel hakların ve hürriyetlerin sınırlanması yoluna gidildiğini ve bunun doğru olmadığını belirtmiştir. Cizrelioğlu'nun önergesi Anayasa ve Adalet Komisyonu tarafından kabul görmemiş ve yapılan oylamada önerge reddedilmiştir.
} 
güvenliğe ve kamu düzenine vurgu yapıldığı söylenebilir (Eroğul, 1974: 154; Kili- Gözübüyük, 2006: 198). Anayasasının 26. maddesinde basın dışı haberleşme araçlarından faydalanma hakkı konusunda değişiklik yapılmıştır. Kişilerin ve siyasi partilerin basın dışı haberleşme ve yayın araçlarından faydalanma hakkına sahip olduğu belirtilmiş; milli güvenliğin, Cumhuriyetin ve genel ahlakın korunması dışında belirtilen araçlara ulaşmanın engellenemeyeceği vurgulanmıştır (Resmi Gazete, 22 Eylül 1971: 2; Kili- Gözübüyük, 2006: 199; Eroğul, 1974: 154- 155). Gazete, dergi ve basınla ilgili yapılan değişiklikte kamu düzeni, milli güvenlik ve genel ahlak konularında tedbir alınabileceği belirtilmiştir.

Anayasanın 29. maddesinde ise derneklerin kurulmasına ve kapatılmasına dair değişiklikler yapılmıştır. Milli güvenliğin, kamu düzeninin ve genel ahlakın korunması için kanunla bazı sınırlamalar getirilebileceği belirtilmiştir. Diğer taraftan hiç kimsenin derneğe üye olmaya ve dernekte üye kalmaya zorlanamayacağı vurgulanmıştır. Derneklerin hakim kararıyla kapatılabileceği, gecikmede sakınca bulunulan hallerde ise hakim kararına kadar yetkili merciler tarafından derneğin faaliyetten alıkonulabileceği belirtilmiştir. Bütün bu değişikliklerle idarenin dernekler üzerindeki nüfuzunun artırıldığı söylenebilir (Kili- Gözübüyük, 2006: 200; Resmi Gazete, 22 Eylül 1971: 2). Anayasanın kişi güvenliğini düzenleyen 30. maddesinde yapılan değişiklikle yakalanan veya tutuklanan kişilerin yirmi dört saat içerisinde hakim karşısına çıkarılmasına ait düzenleme kırk sekiz saate çıkarılmış, toplu suçlarda bu süre yedi gün olarak belirlenmiştir. Bu sürelerden sonra hakim kararı olmaksızın hiç kimsenin hürriyetinden yoksun bırakılamayacağı ifade edilmiştir. Nihayet bu değişiklikle, bireysel tutuklamalarda kolluk kuvvetlerine zaman kazandırılmış, toplu suçlar kavramı maddeye eklenerek yine kolluk kuvvetlerine yetki verilmiştir (Tanör, 1986: 59; Resmi Gazete, 22 Eylül 1971: 2; Eroğul, 1974: 155; Kili- Gözübüyük, 2006: 201). Anayasanın 32. maddesinde yapılan değişiklikle "tabii yargı yolu" ifadesi "kanuni yargı yolu" olarak değiştirilmiş̦tir. Bu maddede yapılan değişiklikle "tabii hakim" kavramı değişikliğe uğramış ve hiç kimsenin "kanunen tabi olduğu mahkemeden" başka bir merci önüne çıkarılamayacağı vurgulanmıştır (Yazıcı, 1997: 127; Kili- Gözübüyük, 2006: 201- 202; Resmi Gazete, 22 Eylül 1971: 2). Yapılan değişiklikle mahkeme kavramına ağırlık verildiği anlaşılmaktadır.

Anayasanın sosyal ve iktisadi haklar bölümünde de iki değişiklik yapılmıştır. İlk olarak kamulaştırma kısmını düzenleyen 38. madde değişikliğe uğramıştır. Kamulaştırma işlemlerine, bir önceki maddeden farklı olarak "taşınmaz mal, kıyıların korunması ve turizm amacıyla yapılacak kamulaştırma" ifadeleri eklenmiştir. Çiftçinin topraklandırılması, ormanların devletleştirilmesi, yeni orman yetiştirilmesi ve iskan projelerinin gerçekleştirilmesi için taksitli ödemelere yirmi yıllık süre konulmuştur. Kıyıların korunması ve turizm amacıyla yapılacak kamulaştırmalarda taksitli ödemenin on yılı aşamayacağı belirtilmiştir. Kamulaştırmada belirlenecek miktarlar konusunda malikin bildireceği vergi değerine göre yapılacak ödemeler konusu, Anayasa Mahkemesi tarafından 12/10/1976 tarihinde iptal edilmiştir (Kili- Gözübüyük, 2006: 203- 204; Resmi Gazete, 20 Ocak 1977: 1- 10). Yine sosyal ve iktisadi haklar bölümünde sendika kurma hakkını düzenleyen 46. maddede değişikliğe gidilmiştir. "Çalışanlar ve işverenler" ifadesi "işçiler ve işverenler" şeklinde düzeltilmiştir. Sendika kurma hakkının kullanılmasına dair esasların kanunla düzenleneceği belirtilmiştir. Diğer taraftan kamu çalışanlarının sendika hakkı anayasadan çıkarılmıştır (Yetkin, 2010: 159; Eroğul, 1974: 155; Kili- Gözübüyük, 2006: 206). Burada dikkat çeken en önemli değişiklik, kamu görevlilerinin sendika kurma hakkının kaldırılmış olmasidır.

Siyasi haklar ve ödevler bölümünde yer alan 60. maddedeki, "milli savunma hak ve ödevi” başlığı "vatan hizmeti" olarak değiştirilmiştir. Yurt savunması kavramı da, vatan hizmeti şeklinde değiştirilmiştir. Vatan hizmetinin Silahlı Kuvvetler veya kamu hizmetlerinde ne şekilde yerine getirileceğinin kanunla düzenleneceği belirtilmiştir (Resmi Gazete, 22 Eylül 1971: 2; Kili- Gözübüyük, 2006: 209- 210; Eroğul, 1974: 155). Vergi ödevini belirleyen anayasanın 61. maddesine eklenen bir paragrafla vergi, resim ve harçların muafiyet ve istisnalarıyla ilgili değişiklik yapmaya Bakanlar Kurulunun yetkili kılınabileceği belirtilmiştir (Kili- Gözübüyük, 2006: 210). Anayasanın 60 ve 61. 
maddelerinde yapılan değişikliklerle herhangi bir kısıtlamaya gidilmediği anlaşılmaktadır (Eroğul, 1974:155).

1961 Anayasası'nın üçüncü kısmı "Cumhuriyetin Temel Kuruluşu” başlı̆ı̆ını taşımaktadır. Bu kısmın birinci bölümünde yer alan TBMM'nin görev ve yetkilerinin açıklandığ 1 64. madde de değişikliğe uğramıştır (Koçaş, 1978: 159- 160) . $^{9}$ Yapılan değişiklikle TBMM tarafindan Bakanlar Kuruluna kanun hükmünde kararname çıkarma yetkisi tanınmıştır. KHK'ların amacı, kapsamı ve süresinin açıkça belirtilmesi gerektiği vurgulanmış, yayımlandıkları gün TBMM’ye sunulması gerektiği ifade edilmiştir. Kararnamelerin Meclis'te öncelikle görüşüleceği vurgulanmıştır. TBMM'de onaylanmayan KHK'ların yayımlandığı gün yürürlükten kalkacağı belirtilmiştir. Bakanlar Kurulu tarafından çıkarılacak KHK' larla temel hak ve hürriyetler ile siyasi hak ve ödevlerin düzenlenemeyeceği ifade edilmiştir. Burada Bakanlar Kuruluna kanun çıkarma yetkisi verilerek yürütmenin gücü artırılmış olmakla birlikte, bu yetkinin sınırsız ve denetimsiz olmadığı anlaşılmaktadır (Tanör, 1986: 56; Resmi Gazete, 22 Eylül 1971: 2- 3; Özdemir, 2011: 265; Kili- Gözübüyük, 2006: 211- 212; Eroğul, 1974:155156). Hükümete kanun hükmünde kararname çıkarma yetkisi verilerek, yasama erkinin kısmi olarak zayıfladığı ve yürütmenin kuvvetlendirildiği söylenebilir (Mazıcı, 1989: 126; Üskül, 2006: 65; Özbudun- Gençkaya, 2010: 28). Gensoru ile ilgili 89. madde de bu dönemde değiştirilmiştir. Millet Meclisi'nin yetkisinde olan gensorunun kimler tarafindan verileceği biraz daha detaylandırılmıştır. $\mathrm{Bu}$ kapsamda, gensorunun bir siyasi parti grubu adına veya en az on milletvekilinin imzasıyla verilebileceği belirtilmiştir. Ayrıca, gensoru önergesinin basılı olarak dağıtılmasına yönelik düzenlemelerin içtüzükte gösterileceği vurgulanmıştır (Kili- Gözübüyük, 2006: 220; Eroğul, 1974: 156; Resmi Gazete, 22 Eylül 1971: 3). Bu değişiklikle her milletvekilinin gensoru önergesi vermesine sinırlama getirilmiş, gensorunun basılması yönündeki bir değişiklikle zamandan tasarruf edilmesi hedeflenmiştir.

Üçüncü kısım ikinci bölümde yer alan "yürütme” alanında da değişiklikler yapılmıştır. Başkomutanlık ve Genelkurmay Başkanlığını açıklayan 110. maddeye eklenen bir cümle ile; Milli Savunma Bakanlığının görev ve yetkileri ile Genelkurmay Başkanlığı ve Kuvvet Komutanlıklarının ilişkilerinin kanunla düzenleneceği belirtilmiştir (Resmi Gazete, 22 Eylül 1971: 3; Kili- Gözübüyük, 2006: 228). Milli Güvenlik Kurulu ile ilgili 111. maddede ise önemli değişiklikler yapılmıştır. Maddenin ilk halinde Milli Güvenlik Kurulu'nun kimler tarafından oluştuğu belirtilmiş ve kuvvet temsilcileri ifadesi yer almıştır. Değişiklikle kuvvet temsilcileri ifadesinin yerine kuvvet komutanlıkları ifadesi konulmuştur. Diğer önemli değişiklik ise, maddenin son paragrafında yer almıştır. Buna göre Milli Güvenlik Kurulu'nun milli güvenlikle ilgili almış olduğu kararlar ve temel görüşleri Bakanlar Kurulu'na "bildirir" ifadesi yerine "tavsiye eder" şeklinde bir değişiklik yapılmıştır (Yazıc1, 1997: 121; KiliGözübüyük, 2006: 229; Eroğul, 1974: 157; Koçak, 2001: 163; Resmi Gazete, 22 Eylül 1971: 3; Öztürk, 2006: 88). Bu da Milli Güvenlik Kurulu'nun ve özellikle askerlerin siyasi irade üzerindeki nüfuzunun artırıldığını göstermektedir.

İdare kısmında "yargı yolu" başlığını taşıyan 114. maddeye bir paragraf eklenmiştir. Maddenin ilk halinde "yargı denetimi" ifadesi yer alırken, değişiklikle birlikte "yargı yolu" kavramı tercih edilmiştir. Bu madde ile idarenin her türlü eylem ve işlemine karşı yargı yolunun açı olduğu belirtilmiş, ancak yarg1 yetkisinin yürütme yetkisini sınırlayacak tarzda kullanılamayacağı ve yargının idari eylem ve işlem niteliğinde karar veremeyeceği vurgulanmıştır. Bu maddede yapılan değişiklikle yargının idare karşısındaki yetki sınırları çizilmiştir (Resmi Gazete, 22 Eylül 1971: 3; Kili- Gözübüyük, 2006: 230; Eroğul, 1974: 157). Anayasanın 119. maddesinde yapılan değişiklikle siyasi partilere giremeyen memurların aynı zamanda sendikalara girmesi engellenmiştir. Bu da özgürlüklerin belirli alanlarda kısıtlandığını göstermektedir (Resmi Gazete, 22 Eylül 1971: 3; Kili- Gözübüyük, 2006: 231- 232;

\footnotetext{
${ }^{9}$ Sadi Koçaş, De Gaulle'den esinlenerek hükümete kanun niteliğinde kararname çıkarma yetkisi verilmesi konusunda CHP Genel Başkanı İsmet İnönü’nün görüşlerini almış ve bu konularda CHP'nin ne düşündüğünü, destekleyip desteklemeyeceğini sormuştur.
} 
Eroğul, 1974: 157- 158). Üniversitelerle ilgili düzenlemelerin yer aldığı anayasanın 120. maddesine bir kısım eklemeler ve çıkarmalar yapılmıştır. Üniversite özerkliğinin üniversite binalarında ve eklerinde suçların ve suçluların kovuşturulmasına engel olamayacağı belirtilmiştir. Üniversitelerin devletin gözetimi ve denetimi altında seçilen organlar eliyle yönetileceği vurgulanmıştır. Üniversitelerle ilgili genel hükümler yanında, üniversitelerde öğrenim ve öğretim hürriyetinin tehlikeye düşmesi ve bunun üniversite organlarınca giderilememesi durumunda Bakanlar Kurulu'nun ilgili kurumun yönetimine el koyacağı belirtilmiştir. Yönetime el koymaya ait usullerin kanunla düzenleneceği vurgulanmıştır (Resmi Gazete, 22 Eylül 1971: 3; Kili- Gözübüyük, 2006: 232- 233). Bu maddede yapılan değişiklikle birlikte, üniversitelerin hiçbir şekilde müdahale edilemez alanlar olmadıkları vurgulanmıştır. Burada özellikle 1968 sonrasında yoğun olarak yaşanan üniversite olaylarından etkilenildiği söylenebilir.

Anayasanın "radyo ve televizyonların idaresi ve haber ajansları" başlığııı taşıyan 121. maddesinde de bazı değişiklikler yapılmıştır. Radyo ve televizyon istasyonlarının ancak devlet eliyle kurulacağ belirtilmiştir. Maddeye eklenen bir paragrafla haber ve programların seçimi, işlenmesi ve sunumunda devletin ülkesi ve milletiyle bölünmez bütünlüğü, cumhuriyetin temel ilkeleri ile milli güvenlik ve genel ahlakın gereklerine uyulması zorunluluğu getirilmiş ve bunların kanunla düzenleneceği belirtilmiştir. Maddeye ayrıca, haberlerin doğruluğunun sağlanması konusu ilave edilmiştir (Resmi Gazete, 22 Eylül 1971: 3; Kili- Gözübüyük, 2006: 233- 234). Sıkıyönetim başlığını taşıyan 124. madde "sıkıyönetim ve savaş" olarak değiştirilmiştir. Bu maddede yapılan değişiklikle, Bakanlar Kurulunun bir aylık sıkıyönetim yetkisi iki aya çıkarılmışıı. Hür demokratik düzeni veya temel hak ve hürriyetleri ortadan kaldırmaya yönelen yaygın şiddet hareketleri hakkında kesin belirtilerin ortaya çıkması durumunda sıkıyönetimin ilan edilebileceği vurgulanmıştır (Maliye Bakanlığı Bütçe ve Mali Kontrol Genel Müdürlüğü, 1993: 160- 161; Kili- Gözübüyük, 2006: 234- 235; Resmi Gazete, 22 Eylül 1971: 4). Bu maddede yapılan değişiklikle sıkıönetimin ilanı biraz daha kolaylaştırılmış, Bakanlar Kurulunun yetkisi ise artırılmıştır.

İktisadi ve mali hükümlerin bulunduğu kısımda yer alan "Sayıştay" ile ilgili 127. madde de değişikliğe uğramıştır. Bu maddeye eklenen bir paragraf ile Silahlı Kuvvetlerin elinde bulunan malların TBMM adına denetlenmesine ait usullerin milli savunma hizmetlerinin gerektirdiği gizlilik esaslarına uygun olarak kanunla düzenleneceği belirtilmiştir (Resmi Gazete, 22 Eylül 1971, Sayı: 13964, s. 4; KiliGözübüyük, 2006: 236). Anayasa değişikliğinde Silahlı Kuvvetlerin elinde bulunan malların denetimi konusunda kanuni düzenleme gerektiği vurgulanarak Silahlı Kuvvetlerin özel bir statüde olduğu ifade edilmiştir (Yazıcı, 1997: 124- 125). Özetle Silahlı Kuvvetleri Sayıştay denetiminden muaf tutarak kurumsal özerkliğinin sağlandığı söylenebilir (Özbudun- Gençkaya, 2010: 28).

Anayasanın yargı ile ilgili kısmında da çeşitli değişiklikler yapılmıştır. Hakimlik mesleğinin açıklandığ 134. maddede yapılan değişiklikle, askeri hakimlerin yaş haddi yanında "yükselme ve emekliliklerinin" de kanunla düzenleneceği vurgulanmıştır. Bu değişiklikle askeri hakimlerin durumları biraz daha netleştirilmiştir (Kili- Gözübüyük, 2006: 239; Resmi Gazete, 22 Eylül 1971: 4). Savc1lıkla ilgili düzenlemeleri içeren 137. madde de değişikliğe uğramıştır. Cumhuriyet savcılarının idari görevleri yönünden Adalet Bakanlığına bağlı oldukları belirtilmiştir. Cumhuriyet savcılarının bütün özlük işleri, disiplin cezaları ve meslekten çıkarılmalarına dair karar verme yetkisi Yüksek Savcılar Kurulu'na verilmiştir. Yüksek Savcılar Kurulu'nun, Adalet Bakanının başkanlığında toplanması hüküm altına alınmıştır. Bu kurulun verdiği kararların kesin olduğuna ve bunlar aleyhine başka mercilere başvuru yapılamayacağına dair karar, Anayasa Mahkemesi tarafından 1977 yılı Eylül ayında iptal edilmiştir (Resmi Gazete, 14 Ocak 1978: 29- 49; Resmi Gazete, 22 Eylül 1971: 4; Kili- Gözübüyük, 2006: 241; Eroğul, 1974: 158). Bu maddede yapılan değişiklikle savcılar açısından Yüksek Savcılar Kurulu'nun etkinliği vurgulanabilir. Ancak, 1977 yılındaki Anayasa Mahkemesi kararı ile Yüksek Savcılar Kurulu'nun sınırsız yetkisi kısıtlanmıştır.

Askeri yargıyla ilgili hükümlerin yer aldığg 138. madde de değiştirilmiştir. Burada yapılan değişiklikle, askeri mahkemelerin asker olmayanlarla ilgili hangi davalara bakacakları 
detaylandırılmıştır. Buna göre askeri mahkemelerin, asker olmayan kişilerin özel kanunda belirtilen askeri suçları ile kanunda gösterilen görevleri ifa ettikleri sırada veya kanunda gösterilen askeri mahallerde askerlere karşı işledikleri suçlara bakmakla görevli olduğu belirtilmiştir (Resmi Gazete, 22 Eylül 1971: 4; Kili- Gözübüyük, 2006: 242). Anayasanın yüksek mahkemeler kısmında yer alan "Yargıtay" başlıklı 139. maddesinde de değişiklik yapılmıştır. Buna göre Yargıtay üyelerinin birinci sınıfa ayrılmış hakimler ve cumhuriyet savcıları ile bu mesleklerden sayılanlar arasından Yüksek Hakimler Kurulu'nca üye sayısının salt çoğunluğu ile seçileceği belirtilmiştir. Yargıtay 1. ve 2. Başkanları ile Cumhuriyet Başsavcısının görev süresinin dört yıl olduğu ve yeniden seçilebilecekleri ifade edilmiştir (Resmi Gazete, 22 Eylül 1971: 4; Kili- Gözübüyük, 2006: 243). Buradaki değişiklikle Yargıtay üyeliğine kimlerin, nasıl seçilecekleri detaylandırılmış ve açıklanmıştır.

1961 Anayasası'nın Danıştay başlıklı 140. maddesinde de bazı değişiklikler yapılmıştır. Burada Danıştay üyelerinin seçilme şartları ve usulleri ayrıntılı bir şekilde açıklanmışıı. Ayrıca, Danıştay Başkanı ve Başkan Sözcüsünün nasıl seçilecekleri de ayrıntılı yazılmıştır (Kili- Gözübüyük, 2006: 244245; Resmi Gazete, 22 Eylül 1971: 4- 5). Diğer taraftan 140. maddeye eklenen bir fikra ile Askeri Yüksek İdare Mahkemesi kurulmuştur. Asker kişilerle ilgili idari eylem ve işlemlerin yargı denetimi Askeri Yüksek İdare Mahkemesi'ne verilmiştir (Yazıcı, 1997: 132). Böylece asker kişilerin askeri mahkemelerde yargılanmaları sağlanarak, sivil yargı alanının dışına çıkarıldıkları söylenebilir. Askeri Yargıtay başlıklı 141. maddede yapılan değişiklikle, Askeri Yargıtay üyelerinin en az albay rütbesinde bulunan birinci sınıf askeri hakimler arasından Askeri Yargitay Genel Kurulu tarafından boş pozisyonun üç katı oranında belirlenecek adaylar arasından Cumhurbaşkanınca seçileceği belirtilmiştir. $\mathrm{Bu}$ değişiklikle en az on yıl hakimlik ve savcılık yapmış olma ile kırk yaşını doldurmuş olma kriterleri kaldırılmıştır (Kili- Gözübüyük, 2006: 245; Resmi Gazete, 22 Eylül 1971: 5).

Anayasada Yüksek Hakimler Kurulu'nun kuruluşunu açılayan 143. maddesi de değişikliğe uğramıştır. Buna göre, Yüksek Hakimler Kurulu üye sayısı on sekiz asıl, beş yedek üyeden, on bir asıl ve üç yedek üyeye düşürülmüştür. Millet Meclisi ve Cumhuriyet Senatosu'nun altı asıl ve iki yedek üye seçim yetkisi kaldırılmış, üyelerin tamamının Yargıtay Genel Kurulu tarafindan, kendi üyeleri arasından, üye tam sayısının salt çoğunluğu ve gizli oyla seçileceği belirtilmiştir. Üyelerin görev süresi dört yıl olup, ilk metinde iki yılda üyelerinin yarısının yenileceği ve hakimlik görevinde iken seçilenlerin yeniden seçilemeyeceği belirtilmişti. Yapılan değişiklikle iki yılda üyelerin yarısının yenilenmesi usulü ve yeniden seçilememe kriteri kaldırılmıştır. İlk metinde Adalet Bakanının toplantılara katılabileceği, ancak oylamaya katılamayacağı belirtilmişti. Yapılan değişiklikle, Adalet Bakanının gerekli gördüğü hallerde toplantılara başkanlık edeceği vurgulanmıştır (Kili- Gözübüyük, 2006: 246-247; Resmi Gazete, 22 Eylül 1971: 5). Bu maddede yapılan değişiklikle, meclislerin kurul üzerindeki doğrudan etkisi kaldırılmış, Yargıtay Genel Kurulunun etkinliği ise artırılmıştır. Diğer taraftan Adalet Bakanının kurul üzerindeki nüfuzu kuvvetlendirilmiştir.

Yüksek Hakimler Kurulu'nun görev ve yetkilerini düzenleyen 144. maddesi de burada değişikliğe uğramıştır. Buna göre, hakimlerin bütün özlük işleri hakkında karar verme yetkisi Yüksek Hakimler Kurulu'nda iken, Adalet Bakanı veya hakkında karar verilen hakimler, disiplin ve meslekten çıkarma cezaları ile ilgili kararların bir defa daha incelenmesini isteyebileceklerine dair bir değişiklik yapılmıştır. Nihayet meslekten çıkarma cezalarına Yüksek Hakimler Kurulu Genel Kurulunun salt çoğunluğu ile karar verileceği belirtilmiştir. Adalet Bakanının bir hakim hakkında disiplin kovuşturması açılması için Yüksek Hakimler Kurulu'na başvurabileceğine dair hüküm, "açılmasını isteyebilir" şeklinde değiştirilmiştir. Hakimlerin denetimi, Yüksek Hakimler Kurulu tarafindan görevlendirilecek üst derecedeki hakimler eliyle yapılırken, yapılan değişiklikle "müfettiş hakimler" eliyle yapılması karar altına alınmıştır. Diğer taraftan sürekli görevle çalışacak olan "müfettiş hakimlerin" Yüksek Hakimler Kurulu tarafından atanması esası belirlenmiştir (Kili- Gözübüyük, 2006: 247- 248; Resmi Gazete, 22 Eylül 1971: 5). Bu maddede yapılan değişiklikle, Adalet Bakanının hem ilgili kurul hem de hakimler 
üzerindeki yetkisi artırılmıştır. Ayrıca, denetim hizmetleri konusunda sürekli bir pozisyon olan "müfettiş hakimlik" kadrosu oluşturulmuştur.

Anayasa Mahkemesi'ne üyelerin seçimini düzenleyen anayasanın 145. maddesi de değişikliğe uğramıştır. Buna göre, ilk metinde yer alan "başsavcı" ifadesi "Cumhuriyet Başsavcısı" olarak değiştirilmiştir. Yasama meclislerinin seçeceği üyelerin üçte iki çoğunlukla seçileceğine dair hüküm, salt çoğunlukla seçileceği seklinde düzeltilmiştir. Ayrıca, meclislerin seçeceği birer üyenin üniversitelerin ilgili bölümlerinden seçmesi gerektiğine dair hüküm kaldırılmıştır. Bu maddede yapılan değişiklikle, meclislerin üye seçimleri konusunda eli rahatlatılmıştır. Anayasa Mahkemesi'nin görev ve yetkilerini açıklayan 147. maddesi de değişikliğe uğramıştır. Anayasa Mahkemesi'nin kanunların ve içtüzüğün anayasaya uygunluğunu denetleyeceğine dair hüküm genişletilmiştir. Yapılan değişiklikle Anayasa Mahkemesi'nin aynı zamanda anayasa değişikliklerinin de anayasada gösterilen şekil şartlarına uygunluğunu denetleyeceği vurgulanmıştır (Kili- Gözübüyük, 2006: 248- 250; Resmi Gazete, 22 Eylül 1971: 5). Bu değişiklikle, yasama meclislerinin yetki alanı daraltılmış, Anayasa Mahkemesi'nin yetki alanı ise genişletilmiştir.

Anayasanın "Dava hakkını" düzenleyen 149. maddesi de değişikliğe uğramıştır. Buna göre, ilk metinde Türkiye Büyük Millet Meclisi’nde temsilcisi bulunan siyasi partilerin veya bunların meclis gruplarının da doğrudan doğruya Anayasa Mahkemesi'nde iptal davası açabileceği belirtilmişti. Yapılan değişiklikle birlikte, yasama meclislerindeki siyasi parti grupları ve Türkiye Büyük Millet Meclisi'nde grubu bulunan siyasi partiler hükmü getirilmiştir. Böylece, temsilci yerine bir parti grubunun bulunması öngörülmüştür. Anayasaya aykırılığın diğer mahkemelerde ileri sürülmesi konusunu ele alan anayasanın 151. maddesi de değişikliğe uğramıştır. Burada yapılan değişiklikle, Anayasa Mahkemesi işin kendisine gelişinden başlamak üzere üç ay içerisinde kararını verir hükmü yerine, "altı ay içerisinde kararını verir ve açıklar" şeklinde bir değişiklik yapılmıştır. Bu da karar sürecinde Anayasa Mahkemesi açısından bir zaman kazanma anlamına gelmektedir. Ayrıca mahkemenin açıklaması da hükme başlanmıştır. Anayasa Mahkemesi'nin kararlarını düzenleyen anayasanın 152. maddesinde de değişiklik yapılmıştır. Burada yapılan değişiklikle, Anayasa Mahkemesi kararlarının gerekçesi yazılmadan açıklanamayacağı belirtilmiştir. Anayasa Mahkemesi'nin iptal kararlarının karar tarihinde yürürlükten kalkacağına dair hüküm, gerekçeli kararın Resmi Gazete'de yayımlandığı tarihte yürürlükten kalkacağ 1 şeklinde değiştirilmiştir. Anayasa Mahkemesi gerekli durumlarda yürürlük tarihini ileri bir tarih olarak belirleyebilmektedir. Bu tarihin karar tarihinden itibaren altı ayı geçemeyeceğine dair hüküm, Resmi Gazete'de yayımlandığı tarihten itibaren bir yılı geçemez şeklinde değiştirilmiştir (Kili- Gözübüyük, 2006: 250- 252; Resmi Gazete, 22 Eylül 1971: 5- 6). Burada yapılan değişiklikte de Anayasa Mahkemesi'nin yürürlüğe ait yetkisi genişletilmiştir.

1961 Anayasası'na 20 Eylül 1971 tarihinde 1488 sayılı Kanunla 9 (dokuz) da geçici madde (geçici 12- 20. maddeler) eklenmiştir. Geçici 12. madde ile; Cumhuriyet Senatosu üyelerinden üçte birinin yenilenmesi ve Cumhuriyet Senatosu ile Millet Meclisi'nde boş bulunan üyelikler için 10 Ekim 1971 tarihinde yapılacak seçimler, 12 Ekim 1973'te yapılması gereken milletvekilleri genel seçimleriyle birlikte yapılmak üzere ertelenmiştir. Cumhuriyet Senatosu üyelerinden süresi dolanların üyelik sıfatlarının seçim yapılıncaya kadar devam edeceği hükme bağlanmıştır. Geçici 13. madde ile; Yargıtay Birinci ve İkinci Başkanlığ ile Cumhuriyet Başsavcılığında 4 yılını doldurmuş olanların yerleri için, anayasa değişikliğinin yürürlüğe girdiği tarihten itibaren bir ay içerisinde yeni seçimlerin yapılacağı belirtilmiştir. Diğer taraftan Yargıtay'ın kuruluşu ve işleyişine dair kanunun altı ay içerisinde çıkarılacağı hükme başlanmıştır (Resmi Gazete, 22 Eylül 1971: 6; Kili- Gözübüyük, 2006: 257).

Anayasaya eklenen geçici 14. madde ile; Danıştay Başkanlığı ve Başkan Sözcüsü olarak dört yılını doldurmuş olanların yerleri için, yürürlük tarihinden itibaren bir ay içerisinde yeni seçim yapılacağı belirtilmiştir. Ayrıca, Danıştay Kanununun altı ay içerisinde değiştirilmesi ve kanunun yürürlüğe girdiği tarihten itibaren bir ay içerisinde, dört yılını tamamlamış Danıştay Daire Başkanlıkları için yeni bir seçim yapılacağı vurgulanmıştır. Belirtilen seçimlere yeniden seçilemeyenlerin Danıştay 
üyesi olması karar altına alınmıştır. Geçici 15. madde ile; Anayasa değişikliğinin yürürlük tarihi itibariyle Yargıtay İkinci Cumhuriyet Başsavcılığı veya Yargıtay Cumhuriyet Savcılığı görevlerinde bulunanların Yargıtay üyesi olacakları belirtilmiştir. Bunlara ait kadroların da Yargıtay'a üye kadrosu olarak geçeceği vurgulanmıştır. Geçici 16. madde ile; Anayasanın 46 ve 119. maddelerinde yapılan değişikliklerin yürürlüğe girdiği tarihte 624 sayılı Kanuna dayanılarak kurulmuş olan kamu hizmetlileri sendikalarının faaliyetinin sona ereceği belirtilmiştir. Kamu hizmetlileri kuruluşlarının kuruluşuna ve sendikaların varlıklarının bu kuruluşlara intikaline dair bir kanunun altı ay içerisinde çıkarılacağı belirtilmiştir. Geçici 17. madde ile; Anayasanın 134, 138, 140 ve 141. maddeleri gereğince askeri yarg1 ile ilgili kanunların altı ay içerisinde değiştirilmesi kararlaştırılmıştır. Bu kanunların gerektirdiği seçim ve atamaların kanunların yürürlüğe girdiği tarihten itibaren bir ay içerisinde gerçekleştirileceği belirtilmiştir (Kili- Gözübüyük, 2006: 257- 258; Resmi Gazete, 22 Eylül 1971: 6).

Anayasanın geçici 18. maddesi ile; Anayasanın 137. maddesinde geçen Yüksek Savcılar Kurulu'nun kuruluşuna dair kanunun altı ay içerisinde çıkarılacağı belirtilmiş̧, ilgili kanun yürürlüğe girene kadar 2556 ve 45 sayılı kanunların değişiklik ve ekleriyle birlikte uygulanmasına devam edileceği belirtilmiştir. Geçici 19. madde ile; Anayasanın 143 ve 144. maddeleri gereğince 45 sayılı Yüksek Hakimler Kurulu Kanununun altı ay içerisinde değiştirilmesi gerektiği belirtilmiştir. Bu geçici madde ile, Yüksek Hakimler Kurulu üyelerinin görev süresinin 45 sayılı Kanunda yapılacak değişiklik sonrasındaki seçim sonuçlarına kadar devam edeceği belirtilmiştir. Geçici 20. maddede ise; Anayasada yapılan değişiklikler nedeniyle çıkarılması zorunlu olan kanunların, geçici maddelerde belirtilenler hariç olmak üzere, anayasa değişikliğinin yürürlüğe girdiği tarihten itibaren bir yıl içerisinde tamamlanması gerektiği belirtilmiştir (Kili- Gözübüyük, 2006: 258- 259; Resmi Gazete, 22 Eylül 1971: 6). Anayasaya eklenen 9 (dokuz) geçici madde ile, anayasada yapılan değişikliklerin kanunlarla uygunluğunu sağlamak amaciyla bir geçiş süreci öngörmüştür. Özetle geçici maddeler, uyum maddeleri olmuştur. Nihayet 1961 Anayasası'nda yapılan bu değişikliklerin yayım tarihi olan, 22 Eylül 1971'de yürürlüğe gireceği ifade edilmiştir.

\section{1961 Anayasası’nda Yapılan Altıncı Değişiklik}

15 Mart 1973'te kabul edilen 1699 sayılı Kanunla 1961 Anayasası'nın 30, 57, 136, 138 ve 148. maddeleri değişikliğe uğramış, 2 (iki) de geçici madde eklenmiştir. 4 madde değişikliği ve 2 de geçici madde eklenmesine dair bu anayasa değişikliği, 20 Mart 1973 tarihli Resmi Gazete'de yayımlanmıştır (Resmi Gazete, 20 Mart 1973: 1). 12 Mart Muhtırasından sonra yapılan üçüncü anayasa değişikliği, 1699 sayılı Kanunla yapılan değişiklik olmuştur (Tanör, 1986: 39).

1961 Anayasası'nın 30. maddesi 4. fikrasında yapılan değişiklikle, yakalanan veya tutuklanan kimsenin en yakın mahkemeye gönderilmesi için gerekli süre hariç kırk sekiz saat, Devlet Güvenlik Mahkemelerinin görev ve yetkilerine giren suçlar ile kanunun açıkça belli ettiği hallerde toplu olarak işlenen suçlarda ve genellikle savaş ve sıkıyönetim hallerinde, kanunlarda gösterilen süre içinde hakim önüne çıkarılacağı hükme bağlanmıştır. Bu sürenin on beş günü geçemeyeceği ve bu süreden sonra hakim kararı olmaksızın kimsenin hürriyetinden yoksun bırakılamayacağı belirtilmiştir. Bu maddede yapılan değişiklikle, tutuklama süresi 24 saatten 48 saate çıkarılmış, Devlet Güvenlik Mahkemelerinin görev alanına giren suçlarda ve olağan üstü süreçlerde tutuklama sürecinin 15 güne kadar uzatılabileceği vurgulanmıştır. Partilerin uyacakları esasları açıklayan 57. maddenin 2. fikrası da 15 Mart 1973'te değişikliğe uğramıştır. Bu maddenin ilk halinde partilerin Anayasa Mahkemesi'ne ne suretle hesap verecekleri ve mali denetimlerinin ise nasıl yapılacağının kanunla düzenleneceği belirtilmişti. Yapılan değişiklikle, partilerin "hangi hallerde ve ne suretle" hesap verecekleri ile denetimlerinin "hangi hallerde ve nasıl yapılacă̆g" şeklinde bir ifade eklenmiştir (Resmi Gazete, 20 Mart 1973: 1; Kili- Gözübüyük, 2006: 200- 201, 209). Bu değişiklikle partilere uygulanacak yaptırımların hangi hallerde yapılması gerektiği konusunun detaylandırılması amaçlanmıştır. 
1961 Anayasası'nın mahkemelerin kuruluşunu düzenleyen 136. maddesine 15 Mart 1973 tarihinde 6 (altı) fikra eklenmiştir. Buna göre; devletin ülkesi ve milletiyle bütünlügü, hür demokratik düzen ve nitelikleri anayasada belirtilen Cumhuriyet aleyhine işlenen ve doğrudan doğruya devlet güvenliğini ilgilendiren suçlara bakmakla görevli Devlet Güvenlik Mahkemelerinin kurulduğu belirtilmiş ve sıkıyönetim ile savaş haline ilişkin hükümlerin saklı olduğu vurgulanmıştır. Devlet Güvenlik Mahkemesinde; bir başkan, dört asıl ve iki yedek üye ile bir savc1 ve yeteri kadar savc1 yardımcısının bulunacağı belirtilmiştir. Başkan, iki asıl ve bir yedek üye ile savcı, birinci sınıfa ayrılmış hakim ve Cumhuriyet savcıları arasından, iki asıl ve bir yedek üye birinci sinıf askeri hakimler arasından, savcı yardımcılarının ise Cumhuriyet savcıları ve askeri hakimler arasından atanacağı belirtilmiştir. Devlet Güvenlik Mahkemesi Başkanlığı, üyeliği, yedek üyeliği, savcıllğı ve savc1 yardımcılığ 1 atamalarında Bakanlar Kurulunca her boş yer için bir misli aday gösterilir. Bu adaylar arasından Devlet Güvenlik Mahkemesi hakimlerinin atanması Yüksek Hakimler Kurulunca, savc1 ve savc1 yardımcılarının atanmaları Yüksek Savcılar Kurulunca, askeri hakimlerden üye, yedek üye ve savcı yardımcılarının atamalarının ise özel kanunlarında gösterilen usule göre yapılacağı belirtilmiştir. Devlet Güvenlik Mahkemesi için sayılan bu görevlilerin görev süresinin üç yıl olduğu, süresi bitenlerin yeniden atanabileceği belirtilmiştir. Devlet Güvenlik Mahkemeleri kararlarının temyiz merciinin Yargıtay'da kurulacak ilgili daireler olduğu ve genel kurulun ise Yargıtay Ceza Daireleri Genel Kurulu olduğu ifade edilmiştir. Devlet Güvenlik Mahkemelerinin kuruluş ve işleyişlerine dair hükümlerin kanunda gösterileceği belirtilmiştir (Resmi Gazete, 20 Mart 1973: 1; Resmi Gazete, 26 Şubat 1976: 15; Kili- Gözübüyük, 2006: 240- 241).

Devlet Güvenlik Mahkemelerinin kurulması, askeri yargıyı güçlendiren bir değişiklik olarak değerlendirilebilir (Yazıcı, 1997: 129; Öztürk, 2006: 88). Bu mahkemeler, yargının bağımsızlığı ve tarafsızlığı açısından bir gerileme sayılabilir (Tanör, 1986: 60). Askeri Yüksek İdare Mahkemesi ve Devlet Güvenlik Mahkemesi, askeri bürokrasinin siviller üzerindeki etkinliğini artırmıştır (Mazıcı, 1989: 125- 126). Askeri kesim, Devlet Güvenlik Mahkemeleri ile sıkıyönetim zamanları dışında da yargıyı etkilemek istemiş̧ir. Devlet Güvenlik Mahkemeleri vasıtasıyla normal zamanlarda da askeri hakimlerin yer alacağ bu mahkemelerle askeri bürokrasi, sivil yönetimdeki etkinliğini devam ettirmek istemiştir (Yazıcı, 1997: 130- 131).

Askeri yargıyı düzenleyen 138. maddenin 4. fikrası da değişikliğe uğramıştır. Bu maddede, "askeri mahkemelerde üyelerin çoğunluğunun hakimlik niteliğine sahip olması şarttır" hükmüne "ancak, savaş halinde bu şart aranmaz" cümlesi eklenmiştir. Bu değişiklikle savaş zamanlarında hakim olmayanların da askeri mahkemelerde görev alması amaçlanmıştır (Resmi Gazete, 20 Mart 1973: 1; Kili- Gözübüyük, 2006: 243). Bu değişiklik, Anayasa Mahkemesi tarafından 15.04.1975 tarihinde iptal edilmiştir (Resmi Gazete, 26 Şubat 1976: 12, 16) ${ }^{10}$. Anayasanın 148. maddesi 2. fikrasında yapılan değişiklikle, Anayasa Mahkemesi'nin Yüce Divan sıfatıyla baktığı davalar dışındaki işleri dosya üzerinden inceler hükmüne, siyasi partilerin kapatılması hakkındaki davalar da eklemiştir (Resmi Gazete, 20 Mart 1973: 1; Kili- Gözübüyük, 2006: 250). Böylece siyasi partilerin kapatılması davalarının da dosya üzerinden incelenemeyeceği hüküm altına alınmıştır.

\footnotetext{
${ }^{10}$ Cumhuriyet Senatosu üye tam sayısının altıda birini aşan üyeler, 15 Mart 1973 tarihli ve 1699 sayılı Kanun ile yapılan bazı değişikliklerin biçim ve esas yönünden değiştirilmesine dair Anayasa Mahkemesi'ne dava açmışlardır. Dava dilekçesinde, 1699 sayılı Kanunun 4. maddesinin iptali isteminin gerekçesi, özetle şu şekilde açıklanmıştır: "Savaş sırasında dahi Türkiye Cumhuriyeti'nin adalet dağıtımında Askeri Ceza Kanunumuz hükümlerine uyulması, bu yönden hâkimlik niteliğini taşıyanların çoğunlukta olması zorunludur. Savaş halinde birçok hukukçu yedek subaylık görevine çağırılacağından, hâkim ihtiyacının fazlasıyla karşılanması olanağı vardır. Bu nedenlerle, gerekçesi güç anlaşılır bu değişiklik, hukuk devleti ilkeleriyle uzlaşacak nitelikte değildir. Anayasa'nın 132. maddesinden itibaren getirilen yargı ve yargılama İlkeleriyle bağdaşmayan bu değişikliğin iptali uygun olacaktır." Nihayet Anayasa Mahkemesi, anayasanın 138. maddesi 4. fikrasını değiştiren "ancak, savaş halinde bu şart aramaz" kuralının anayasanın 9. maddesindeki "devlet şeklinin cumhuriyet olduğu hakkındaki anayasa hükmünün değiştirilemeyeceği ve değiştirilmesinin teklif edilemeyeceğine" ilişkin biçim kuralına aykırı olduğuna ve bu nedenle iptaline, iki karşı oya mukabil oy çokluğu ile kabul etmiş̧ir.
} 
15 Mart 1973'te yapılan anayasa değişikliğinde, anayasaya 2 (iki) geçici madde eklenmiştir. Geçici 21. madde ile, sıkıyönetimin kaldırıldığı tarih itibariyle sıkıyönetim mahkemelerinde görülmekte olan davaların sonuçlandırılıncaya kadar devam edeceği belirtilmiştir. Kamu davası açılmamış dosyalar ile duruşmanın tatiline karar verilmiş davaların durumlarına, niteliklerine ve kanun hükümlerine göre görevli ve yetkili mercilere verileceği belirtilmiştir. Geçici 22. madde ile, 1 Kasım 1972 tarihinde TBMM'de grubu bulunup da 30 Mart 1973 tarihine kadar grubunu muhafaza etmiş ve Milletvekili Genel Seçimlerine katılma niteliği kazanmış olan siyasi partilere de anayasanın 56. maddesindeki şartlar aranmaksızın, kanunun öngördüğü ölçüye göre devletçe yardım yapılacağı hükme bağlanmıştır (Resmi Gazete, 20 Mart 1973: 1; Kili- Gözübüyük, 2006: 259; Yazıc1, 1997: 128- 129).

\section{8. $\quad 1961$ Anayasası’nda Yapılan Yedinci Değişiklik}

1961 Anayasası'nda yedinci kez yapılan değişiklik, 16 Nisan 1974 tarihli ve 1801 sayılı Kanunla yapılmıştır. Bu değişiklik, 22 Nisan 1974 tarihli ve 14866 sayılı Resmi Gazete'de yayımlanmıştır. Burada 1961 Anayasası'nın 68. maddesi değiştirilmiş, geçici 11. madde ise yürürlükten kaldırılmıştır (Resmi Gazete, 22 Nisan 1974: 1).

1961 Anayasası'nın 68. maddesi, milletvekili seçilme yeterliliğini açıklamaktadır. Burada hangi durumlarda milletvekili seçilinemeyeceği de açıklanmıştır. Bu kapsamda, taksirli suçlar hariç olmak üzere beş yıldan fazla hapis cezasıyla veya zimmet, ihtilas, irtikap, rüşvet, hırsızlık, dolandırıcılık, sahtecilik, inancı kötüye kullanma, dolanlı iflas gibi yüz kızartıcı suçlardan biriyle kesin olarak hüküm giymiş olanların, affa uğramış olsalar da, milletvekili seçilemeyecekleri hükmüne yer verilmişti. 1974 yılında 1801 sayılı Kanunla yapılan değişiklikte, "affa uğramış olsalar da" ifadesi maddeden çıkarılmıştır (Kili- Gözübüyük, 2006: 213). Böylece, belirtilen suçlardan ceza alan ve sonra da affedilen kişilerin milletvekilliği önündeki engel kaldırılmıştır.

Anayasanın 68. maddesinde yapılan değişiklikle, uzun süredir siyasi yasaklı olan eski DP'lilerin siyasi haklarının iadesinin amaçlandığı söylenebilir. Bu değişiklikle, toplum içerisindeki ikiliklerin, ayrışmaların giderilmesi amaçlanmıştır. Nihayet yapılması teklif edilen değişiklikle ilgili Cumhuriyet Senatosu'nda yapılan görüşmelerde AP Grubu adına konuşan Şeref Kayalar, yapılacak değişikliğin milli birlik, beraberlik ve özlenen kardeşlik duygularını güçlendireceğini belirtmiştir (CSTD, 09.04.1974: 112). Yine Milli Birlik Grubu adına söz alan Kadri Kaplan da yapılan değişiklikle ilgili görüşlerini aktarmıştır. Kaplan, geçmişteki olayların haklılığı veya haksızlığı üzerinde tartışmanın toplum yararına huzur getireceğine inanmadıklarını belirtmiş, yeni doğan şartlarla birlikte yapılacak değişikliğin düşünce ve vicdanlarda ferahlık yaratacağını vurgulamıştır (CSTD, 09.04.1974: 113). Kadri Kaplan'ın yapmış olduğu bu konuşma, Cumhuriyet Senatosu'ndaki askerlerin değişikliğe sıcak baktıklarını göstermektedir. Siyasi nedenlerle siyasi hakları kısıtlananlar hariç, sayılı suçlar (zimmet, rüşvet, hırsızlık, sahtecilik vs.) nedeniyle mahkum olanların milletvekilliği önündeki engellerinin kaldırılması, zaman zaman tartışmalara neden olmuştur.

1961 Anayasası'nın geçici 11. maddesi ise, 1974 y1lında 1801 sayılı Kanunla yürürlükten kaldırılmıştır. Bu madde şu şekilde idi; "Yüz kızartıcı olmayan bir suçtan kesin hüküm giydikten sonra, bu Anayasanın halkoyu ile kabulünden önce affedilmiş bulunanlar, 68. maddedeki seçilme yasağına tabi değildirler (Kili- Gözübüyük, 2006: 256; Resmi Gazete, 22 Nisan 1974: 1).” Anayasanın 68. maddesinde yapılan değişiklikle, geçici 11. madde hükümsüz hale gelmiştir. Bu nedenle, 1801 sayılı Kanunla geçici 11. madde yürürlükten kaldırılmıştır. 1974 değişikliği ile birlikte 1961 Anayasası, toplamda yedi kez değiştirilmiştir. Yapılan değişikliklerle birlikte 1961 Anayasası, ilk halinden önemli ölçüde farklılaşmıştır (Öztürk, 2006: 84). 


\section{SONUÇ}

Anayasal metinler ve uygulamalar Türk tarihinde uzun bir geçmişe sahip olmakla birlikte, özellikle 20. yüzyılda hazırlanmış olan anayasa metinleri doğrudan günümüzü etkilemektedir. Anadolu'da kurulan yeni Türk devletinin 1921'deki ilk anayasasından sonra 1924 yılında ikinci anayasa hazırlanmış ve nihayet çalışmamızın konusunu oluşturan 1961 Anayasası'na ulaşılmıştır. Her yeni anayasa, hiç şüphesiz kendi tarihindeki anayasal birikim üzerine inşa edilmektedir. Nihayet 1961 Anayasası hazırlanırken, daha önceki Türk anayasaları çalışmanın esas dayanak noktasını oluşturmuştur. Diğer taraftan bu anayasanın hazırlanmasında çağdaş anayasal gelişmeler de dikkate alınmıştır. 27 Mayıs Darbesi sonrasında hazırlanmış olan bu anayasa, 1950- 1960 dönemindeki siyasi gelişmelerden doğrudan etkilenmiştir. 1961 Anayasası'nı hazırlamış olan Kurucu Meclis üyelerinin belirtilen siyasi dönemin tanıkları olması, bu etkiyi desteklemektedir. Nihayet hazırlanmış olan 1961 Anayasası, 9 Temmuz 1961'de yapılan referandum ile kabul edilmiştir.

1961 Anayasası'nın temel haklar ve hürriyetler başta olmak üzere çalışma hayatı, sendika kurma hakk1, toplu sözleşme ve grev hakkı, basın ve haberleşme hürriyeti, siyasi haklar gibi konularda kişi haklarına ve hürriyetlerine ağılık vermesi, buna karşılık yürütmenin otoritesini sınırlayıcı hükümler içermesi, bu anayasanın yürürlükte olduğu süre içerisinde sıkça tartışılmasına neden olmuştur. 1961 Anayasası'nın hürriyetçi ve özgürlükçü yapısı, 1961 yılına kadar arzuladığı ortamı bulamayan sosyalist kesimin örgütlenmesini ve kuvvetlenmesini sağlamış, bu dönem aynı zamanda marjinal örgütlerin de oluşumuna zemin hazırlamıştır. İdeolojik yapılanmanın yoğun olduğu bu dönemde siyasi partiden dernek ve sendikalara kadar uzanan bir kurumsallaşmanın yaşandığı görülmektedir. 1961 Anayasası'nın içeriğini çok iyi kavrayan bu kesim, anayasanın uygulanması konusunda siyasi iradeye sıkça uyarılarda bulunmuştur. Diğer taraftan bu dönemde yaşanan olaylar, hem dönemin hükümetlerini hem de toplumun büyük çoğunluğunu rahatsız etmeye başlamıştır. Bütün bu olaylar, anayasa değişikliği konusunu da gündeme taşımıştır.

Bu kapsamda, 1961 Anayasası'nda yedi kez değişiklik yapılmıştır. İlk değişiklik 1969 yılı Kasım ayında gerçekleştirilirken, en son değişiklik 1974 yılı Nisan ayında gerçekleştirilmiştir. 1961 Anayasası ilk kabulünde 157 ana madde ve 11 de geçici maddeden oluşturulmuştur. 1961 Anayasası'nda 1969- 1974 yılları arasında 46 ana madde değiştirilmiş, 12 geçici madde eklenmiş, 2 geçici madde ise yürürlükten kaldırılmışıı. Anayasa Mahkemesi ise yapılan değişikliklerden 4'ü hakkında iptal kararı vermiştir. Nihayet, 1961 Anayasası'nın ilk halinin önemli oranda değiştirildiğini söyleyebiliriz. 1960'lı y1llarda yaşanan siyasal ve toplumsal gelişmeler özellikle 1971 sonrasında yapılan anayasa değişikliklerine zemin hazırlamıştır. AP'nin iktidarı döneminde isteyip de gerçekleştiremediği değişikliklerin önemli bir kısmı, 12 Mart Muhtırasından sonra gerçekleştirilmiştir.

Koalisyonlu yılların hakim olduğu 1961 - 1965 yılları arasında anayasada herhangi bir değişiklik yapılmamış, AP'nin tek başına iktidarda olduğu 1965- 1971 yıllarında ise üç değişiklik yapılmıştır. Anayasada yapılan ilk değişiklik ise 6 Kasım 1969 tarihli olup, siyasi yasaklı DP'lilerin milletvekili seçilme yasağının önündeki engelin kaldırılması şeklinde gerçekleşmiştir. Bu değişiklik çeşitli siyasi nedenlerle 1969 seçimlerinden sonraya bırakılmıştır. Anayasa Mahkemesi'nin 16 Haziran 1970 tarihli kararı ile bu değişiklik iptal edilmiş ve nihayet 16 Nisan 1974 tarihli 1801 sayılı Kanunla tekrar anayasadan çıkarılmıştır. Böylece, 1960'lı yıllar boyunca siyasi hakları kısıtlanmış olan DP'lilerin siyasi hakları iade edilmiştir.

AP iktidarı döneminde yapılan ikinci ve üçüncü değişiklik seçim tarihlerinde yapılan düzenleme ve ormanların korunmasına yönelik olmuştur. 1961 Anayasası'nda yapılan en köklü değişiklikler ise 12 Mart Muhtırasından sonra yapılmıştır. Muhtırada anayasa değişikliğine yer verilmemiş olmakla birlikte, dönemin sosyal ve siyasal koşulları birçok kesimin anayasa değişikliği konusuna odaklanmasına neden olmuştur. 1971 yılı Haziran ayında iki maddede değişiklik yapılırken, 20 Eylül 1971 tarihinde 35 maddede değişiklik yapılmış ve 9 da geçici madde anayasaya eklenmiştir. 1961 Anayasası'nda yapılan 
en köklü değişikliğin 1971 yılı Eylül ayında gerçekleştirildiğini söyleyebiliriz. Burada yapılan değişiklikler, 1961 sonrası anayasal rejimini de doğrudan etkilemiştir.

1971 yılı Eylül ayında yapılan anayasa değişikliklerinde, temel haklar ve hürriyetler kısmında önemli değişiklikler yapılmış, milli güvenliğin ve kamu düzeninin korunması için temel hakların ve hürriyetlerin kısıtlanabileceği kabul edilmiştir. Aynı gerekçelerle gazetelerin ve dergilerin toplatılabileceği hükme bağlanmıştır. Hakim kararı olmadan yapılan tutuklama süresi 48 saate çıkarılmış, tabii hakim kavramından vazgeçilerek "kanunen tabi olduğu mahkeme" kavramına geçilmiştir. Bakanlar Kuruluna kanun hükmünde kararname çıkarma yetkisi verilmiş, her milletvekilinin gensoru önergesi verme yetkisi sınırlandırılmıştır. Burada, Bakanlar Kurulunun yetkisinin artırıldığı ve korunduğu söylenebilir. Diğer taraftan Milli Güvenlik Kurulu kararlarının Bakanlar Kuruluna "bildirilmesi" usulünden vazgeçilerek "tavsiye eder" şeklinde bir değişiklik yapılmıştır. Bu değişiklik ile, Milli Güvenlik Kurulunun yürütme üzerindeki etkisinin kuvvetlendirildiği görülmektedir.

Eylül ayında yapılan diğer bir değişiklik ise memurların sendikalara üye olma haklarının kaldırılmış olmasıdır. Bu karar, sendikal haklar konusunda bir gerileme olarak değerlendirilebilir. 19681971 yıllarında üniversitelerde yoğun olarak yaşanmış olan olaylar, üniversitelerin özerkliği konusunda da değişiklik yapılmasına neden olmuştur. Anayasada yapılan değişiklikle, üniversite özerkliğinin üniversite binalarında ve eklerinde suçların ve suçluların kovuşturulmasına engel olamayacağı belirtilmiştir. Böylece, hükümetin ve kolluk kuvvetlerinin suç kovuşturması durumlarında üniversitelerde gerekli tedbirleri alabileceği vurgulanmıştır. Diğer taraftan Bakanlar Kurulunun bir aylık sıkıyönetim yetkisi iki aya çıkarılmıştır. Askeri Yüksek İdare Mahkemesi kurulmuş, askeri mahkemelerin asker olmayan kişileri hangi koşullarda yargilayabilecekleri açıklanmıştır. Adalet Bakanının bir hakim hakkında disiplin kovuşturması açılması için Yüksek Hakimler Kuruluna başvurabileceğine dair hüküm, "açılmasını isteyebilir" şeklinde düzeltilmiştir. Böylece, Adalet Bakanının hakimler ve Yüksek Hakimler Kurulu üzerindeki etkisi artırılmıştır.

15 Mart 1973 tarihinde ise anayasada 5 madde değiştirilmiş, metne 2 de geçici madde eklenmiştir. Burada yapılan en önemli değişikliklerden birisi Devlet Güvenlik Mahkemelerinin kurulması olmuştur. Cumhuriyet aleyhine ve devlet güvenliğine yönelik işlenen suçların bu mahkemelerde görülmesi öngörülmüştür. Devlet Güvenlik Mahkemelerinin görev alanına giren suçlarda tutuklama süresinin 15 güne kadar uzatılabileceği belirtilmiştir. Askeri mahkemelerde savaş hallerinde hakimlik mesleğinden olmayanların da üye olabileceklerine dair hüküm, 15 Nisan 1975 tarihinde Anayasa Mahkemesi tarafından iptal edilmiştir. Her iki değişiklik de askeri yargının otoriter bir yapıya kavuşturulmak istendiğini göstermektedir. Diğer taraftan yapılan değişiklikle, siyasi partilerin kapatılma davalarının dosya üzerinden incelenemeyeceği hüküm altına alınmıştır. Nihayet 16 Nisan 1974 tarihinde yapılan değişiklikle, ceza aldıktan sonra affa uğrayanların önündeki siyasi engeller kaldırılmıştır.

1961 Anayasası'nın dönemin siyasi ve sosyal koşulları açısından hürriyetçi bir içeriğe sahip olduğu söylenebilir. Kişi haklarının ve hürriyetlerinin sağlanması, hiç şüphesiz demokrasi kültürünün gelişmesine de katkı sağlayacak bir durumdur. Bu anlamda, antidemokratik bir süreçte hazırlanmış olan 1961 Anayasası'nın hürriyetçi içeriğinin zengin olduğunu ifade edebiliriz. Diğer taraftan ise, 1961 Anayasası askeri ve bürokratik vesayetin kuvvetlenmesini sağlamıştır. Anayasa ile oluşturulan kimi kurumlar, siyasal çoğunluğun kontrolünü ve denetimini sağlamayı amaçlamıştır. Bu kapsamda, 1961 Anayasası'nın bir taraftan hürriyetçi içeriğe sahip olduğunu, diğer taraftan ise siyasal çoğunluğun yetkilerini kısıtlayıcı bir içeriğe sahip olduğunu göstermektedir. 1960'lı yıllarda yaşanmış olan toplumsal olaylar, ilgili hükümetleri oldukça zor durumda bırakmıştır. Bu olaylar, dönemin yöneticilerini 1961 Anayasası'nda değişiklik yapmaya zorlamıştır. Nihayet yapılan değişikliklerle yürütmenin gücü artırılmış ve askeri bürokrasi kuvvetlendirilmiştir. Kişi haklarında ve hürriyetlerinde yapılan düzenleme, geriye gidiş olarak değerlendirilse de, birçok kaosun yaşandığı yıllar açısından 
bakıldığında yapılan değişikliklerin normal karşılanabileceği söylenebilir. Hak ve hürriyet odaklı bir sistem, hiç şüphe yok ki ideal yönetimin en temel özelliğidir. Nihayet şunu söyleyebiliriz ki, kişi hakları ve hürriyetleri kötüye kullanılmadığı, toplumsal kaoslara neden olmadığı ve bir başkasının hürriyetini kısıtlamadığı sürece bir anlam ifade edebilir.

\section{KAYNAKÇA}

\section{A. Arşiv Belgeleri}

\section{A1. Başbakanlık Cumhuriyet Arşivi}

BCA, Dosya: D6, Fon Kodu: 030.01 Yer No: 54.327.5, 1- 2.

$B C A$, Dosya: D6, Fon Kodu: 030.01 Yer No: 54.327.5, 16- 17.

BCA, Dosya: C4, Fon Kodu: 030.01 Yer No: 47.280.5, 8.

BCA, Dosya: C4, Fon Kodu: 030.01 Yer No: 47.280.5, 14.

\section{A2. Yayınlanmış Amerika Dışişleri Bakanlığı Arşivi}

Foreıgn Relatıons of the United States, 1969- 1976, Eastern Europe; Eastern Mediterranean, Volume

XXIX, Editors: James E. Miller, Douglas E. Selvage, Laurie Van Hook, United States Government Printing Office, Washington 2008, Document 423.

\section{B. Resmi Yayınlar}

\section{B1. Resmi Gazete}

Ceride-i Resmiye, 7 Şubat 1337 (7 Şubat 1921).

Resmi Ceride, 24 Mayıs 1340 (24 Mayıs 1924).

Resmi Gazete, 20 Temmuz 1961, Say1: 10859.

Resmi Gazete, 12 Kasim 1969, Say1: 13349.

Resmi Gazete, 22 Nisan 1970, Say1: 13478.

Resmi Gazete, 7 Haziran 1971, Sayı: 13858.

Resmi Gazete, 2 Temmuz 1971, Say1: 13883.

Resmi Gazete, 22 Eylül 1971, Say1: 13964.

Resmi Gazete, 20 Mart 1973, Sayı: 14482.

Resmi Gazete, 22 Nisan 1974, Say1: 14866.

Resmi Gazete, 26 Şubat 1976, Sayı: 15511.

Resmi Gazete, 20 Ocak 1977, Say1: 15825 Mükerrer.

Resmi Gazete, 14 Ocak 1978, Say1: 16169.

\section{B2. Cumhuriyet Senatosu Tutanak Dergisi}

CSTD, 4 Haziran 1970, Birinci Dönem, Yetmiş yedinci Birleşim, Cilt: 59.

CSTD, 12 Eylül 1971, Birinci Dönem, Yüz on üçüncü Birleşim, Cilt: 66.

CSTD, 13 Eylül 1971, Birinci Dönem, Yüz on dördüncü Birleşim, Cilt: 67.

CSTD, 14 Eylül 1971, Birinci Dönem, Yüz on beşinci Birleşim, Cilt: 67.

CSTD, 20 Eylül 1971, Birinci Dönem, Yüz on altıncı Birleşim, Cilt: 67. 
CSTD, 21 Eylül 1971, Birinci Dönem, Yüz on yedinci Birleşim, Cilt: 67.

CSTD, 28 Eylül 1971, Birinci Dönem, Yüz on dokuzuncu Birleşim, Cilt: 67.

CSTD, 9 Nisan 1974, On üçüncü Toplantı, Kırk dördüncü Birleşim, Cilt: 14.

\section{B3. Kurucu Meclis ve Millet Meclisi Tutanak Dergisi}

KMTD, 27 Mayıs 1961, On beşinci Birleşim, Cilt: 2.

MMTD, 8 Şubat 1967, İkinci Dönem, 49. Birleşim, Cilt: 12.

MMTD, 9 Şubat 1967, İkinci Dönem, 50. Birleşim, Cilt: 12.

MMTD, 12 Mart 1971, Üçüncü Dönem, 70. Birleşim, Cilt: 12.

MMTD, 28 Ağustos 1971, Üçüncü Dönem, 157. Birleşim, Cilt: 17.

MMTD, 5 Eylül 1971, Üçüncü Dönem, 162. Birleşim, Cilt: 17.

\section{Yerli ve Yabancı Gazeteler}

Cumhuriyet, 19 Mart 1966.

Cumhuriyet, 22 May1s 1969.

Cumhuriyet, 29 Mayıs 1969.

Cumhuriyet, 17 Haziran 1970.

Cumhuriyet, 10 Mayıs 1971.

Cumhuriyet, 12 May1s 1971.

Cumhuriyet, 13 May1s 1971.

Hürriyet, 1 Mayıs 1971.

Milliyet, "Millet evet diyor", 10 Temmuz 1961.

Milliyet, 25 Haziran 1962.

Milliyet, 24 Ağustos 1967.

Son Havadis, 29 May1s 1961.

Son Havadis, 10 Temmuz 1961.

The Times, May 20, 1969.

The Times, Oct 8, 1969.

\section{Siyasi Parti Yayınları}

Adalet Partisi, Adalet Partisi Genel Başkanı ve Başbakan Süleyman Demirel'in İki Konuşması ve Bir Tebliğ, Adalet Partisi Genel Merkez Neşriyatı: 30, Ankara 1967.

Adalet Partisi, Başbakan Süleyman Demirel'in 16. Basın Toplantısı (24 Ocak 1970), Ankara 1970.

Adalet Partisi, Adalet Partisi Genel Başkanı ve Başbakan Süleyman Demirel'in AP Beşinci Büyük Kongresini Açı̧ Konuşması (21 Ekim 1970), Ayyıldız Matbaası, Ankara 1970.

Adalet Partisi, Oniki Mart ve Sonrası, Cilt: 2, AP Genel Merkez Yayınları No: 48, Ayyıldız Matbaası, Ankara 1972.

Cumhuriyet Halk Partisi, CHP XX. Kurultayı Parti Meclisi Raporu (3 Temmuz 1970), Ulusal Basımevi, Ankara 1970.

Demokratik Parti, 72 'ler Hareketi ve Demokratik Parti, Demokratik Parti Yayınları, Ankara 1971. 


\section{E. Telif ve Tetkik Eserler}

Ahmad, Feroz, (2010), Demokrasi Sürecinde Türkiye (1945-1980), Türkçeleştiren: Ahmet Fethi, 4. Bask1, Hil Yayınları, İstanbul.

Akıncı, Abdulvahap (2013), "Türkiye'de Askeri Vesayetin Tesisi ve Demokratikleşmeye Olan Etkisi”, Akademik Incelemeler Dergisi (Journal of Academic Inquiries), Cilt/Volume: 8, Say1/Number: 1, Y11/Year: 2013, s. 93- 123.

Akınc1, Abdulvahap (2014), “Türkiye'nin Darbe Geleneği: 1960 ve 1971 Müdahaleleri”, Eskişehir Osmangazi Üniversitesi IIIBF Dergisi, Nisan 2014, 9/1, s. 55- 72.

Akşin, Sina, (2017), Kısa Türkiye Tarihi, Türkiye İş Bankası Kültür Yayınları, İstanbul.

Arcayürek, Cüneyt, (1992), Demirel Dönemi 12 Mart Darbesi (1965-1971), Bilgi Yayınları, Ankara.

Arcayürek, Cüneyt, (1985), Yeni Demokrasi Yeni Arayışlar 1960- 1965, Bilgi Yayınları, Ankara.

Ateş, Turan, (2007), Demokrasi, Siyasi Partiler ve Seçim, Beta Yayınları, İstanbul.

Aybar, Mehmet Ali, (1967), Hodri Meydan, Türkiye İşçi Partisi Mecliste: 4, Ankara Basımevi, Ankara.

Batur, Muhsin, (1985), Anılar ve Görüşler (Üç Dönemin Perde Arkası), Milliyet Yayınları: 47, İstanbul.

Belli, Mihri, (2000), İnsanlar Tanıdım (Mihri Belli’nin Anılarl), Doğan Kitapçılık Yayını, İstanbul.

Belli, Mihri, (1970), Yazılar 1965-1970, Sevinç Matbaas1, Ankara.

Berkes, Niyazi, (2004), Türkiye'de Çağdaşlaşma, Yayına Hazırlayan: Ahmet Kuyaş, Yapı Kredi Yayınları, 6. Bask1, İstanbul.

Boran, Behice, (1992), Savunma, Sosyalist Yayınlar: 1, Pele-Sor Basım-Yayın, İstanbul.

Bozbeyli, Ferruh, (2009), Yalnız Demokrat, Hazırlayanlar: İhsan Dağı- Fatih Uğur, Timaş Yayınları, İstanbul.

Bozkurt, Gülnihal, (1994), “Tanzimat ve Hukuk”, Tanzimat'ın 150. Yıldönümü Uluslararası Seтровуити (31 Ekim- 3 Kasım 1989), Türk Tarih Kurumu Basımevi, Ankara, s. 271- 286.

Burçak, Rıfk1 Salim, (1998), Türkiye'de Askeri Müdahalelerin Düşündürdükleri, Gazi Üniversitesi Basın- Yayın Yüksekokulu Matbaası, Ankara.

Cook, Steven A., (2008), Yönetmeden Hükmeden Ordular (Çev. Bahar Şahin), Hayykitap Yayını, İstanbul.

Çavdar, Tevfik, (1996), Türkiye'nin Demokrasi Tarihi (1950- 1995), İmge Kitabevi Yayınları, Ankara.

Çolak, Fatma Nesibe - Abdulvahap Akıncı, (2018), "Darbe Bağlamında Osmanlı'dan 1980'e Kadar Ordu- Siyaset İlişkisi”,, Uluslararası Medeniyet Çalışmaları Dergisi (The Journal of International Civilization Studies), Volume III/ Issue I, Nevşehir, 2018, s. 53- 69.

Demirel, Süleyman, (1973), 1971 Buhranı ve Aydınlığa Doğru, Doğuş Matbaası, Ankara.

Demirel, Süleyman, (1977), Büyük Türkiye, İkinci Baskı, Dergah Yayınları, İstanbul.

Eroğul, Cem, (1974), Anayasayı Değiştirme Sorunu (Bir Mukayeseli Hukuk İncelemesi), Ankara Üniversitesi Siyasal Bilgiler Fakültesi Yayınları No: 371, Sevinç Matbaası, Ankara.

Gevgilili, Ali, (1987), Yükseliş ve Düşüs, Bağlam Yayınları, İstanbul.

Güneş, Turan, (1983), Araba Devrilmeden Önce, Kaynak Yayınları, İstanbul.

İpekçi, Abdi, (1969), Liderler Diyor ki, Ant Yayınları, İstanbul. 
Karpat, Kemal H., (2010), Türk Demokrasi Tarihi, Timaş Yayınları, İstanbul.

Kayalı, Kurtuluş, (2012), Ordu ve Siyaset (27 Mayıs- 12 Mart), 5. Baskı, İletişim Yayınları, İstanbul.

Koçak, Cemil, (2011), "Siyasi Tarih (1923-1950)”, Türkiye Tarihi 4 Çağdaş Türkiye 1908- 1980, Yayın Yönetmeni: Sina Akşin, Cem Yayınevi, İstanbul, s. 127- 211.

Koçak, Levent, (2001), “Türkiye'de Ordu- Siyaset İlişkileri ve Askeri Müdahaleler”, Demokrasi Sorunu ve Türk Demokrasisi, Derleyen: Davut Dursun, Şehir Yayınları, İstanbul, s. 135- 204.

Koçaş, Sadi, (1978), 12 Mart Anıları, Tomurcuk Matbaası, İstanbul.

Kili, Suna- Gözübüyük, A. Şeref, (2006), Sened-i İttifak'tan Günümüze Türk Anayasa Metinleri, 3. Baskı, Türkiye İş Bankası Yayınları, İstanbul.

Kili, Suna, (2001), Türk Devrim Tarihi, Türkiye İş Bankası Yayını, İstanbul.

Maliye Bakanlığı Bütçe ve Mali Kontrol Genel Müdürlüğü, (1993), Savunma ve Güvenlik Hizmetleri (1924-1993), Ankara Üniversitesi Basımevi, Ankara.

Mazıc1, Nurşen, (1989), Türkiye'de Askeri Darbeler ve Sivil Rejime Etkileri, Gür Yayınları, İstanbul.

Özbudun, Ergun, (2011), Otoriter Rejimler, Seçimsel Demokrasiler ve Türkiye, İstanbul Bilgi Üniversitesi Yayınları, İstanbul.

Özbudun, Ergun- Gençkaya, Ömer Faruk, (2010), Türkiye'de Demokratikleşme ve Anayasa Yapımı Politikası, Doğan Kitap Yayınları, İstanbul.

Özdemir, Hikmet, (2011), "Siyasi Tarih (1960- 1980)", Türkiye Tarihi 4 Çă̆daş Türkiye 1908- 1980, Yayın Yönetmeni: Sina Akşin, Cem Yayınevi, İstanbul, s. 227- 296.

Öztürk, Osman Metin, (2006), Ordu ve Politika, 2. Bask1, Fark Yayınları, Ankara.

Selçuk, İlhan, (27 Nisan 1971), "Hoş geldin Tanzimat kafası", Cumhuriyet Gazetesi, s. 2- 2.

Soner, Şükran, (2008), Bizim 68'liler, Cumhuriyet Kitapları, İstanbul.

Tanör, Bülent, (1986), Ikki Anayasa (1961- 1982), Beta Dağıtım Yayını, İstanbul.

Tosun, Ramazan, (1997), Türkiye Cumhuriyeti Tarihi (Kuruluş Dönemi), 2. Bask1, Erciyes Üniversitesi Yayın1, Kayseri.

Tunçkanat, Haydar, (1996), 27 Mayıs 1960 Devrimi (Diktadan Demokrasiye), Çağdaş Yayınları, İstanbul.

Türkiye İşçi Partisi Karşıyaka İlçesi Yönetim Kurulu, (1966), TIP (Köylüye Toprak Herkese İş), Zühal Matbaası, İzmir.

Üskül, Zafer, (2006), Türk Demokrasisi'nde 130 Yll (1876- 2006), Prof. Dr. Bülent Tanör'ün Anısına Türkiye'de Demokratikleşme Perspektifleri, TÜSİAD Yayını, İstanbul.

Yazıc1, Serap, (1997), Türkiye'de Askeri Müdahalelerin Anayasal Etkileri, Yetkin Yayınları, Ankara.

Yetkin, Çetin, (2010), Türkiye'de Askeri Darbeler ve Amerika, Yeniden Anadolu ve Rumeli Müdafaa-i Hukuk Yayınları, Antalya. 


\section{EK-1}

1961 ANAYASASI'NDA YAPILAN DEĞİŞİKLIKKLER ${ }^{11}$

\begin{tabular}{|c|c|c|c|c|c|}
\hline SIRA & $\begin{array}{l}\text { DEĞİŞIKLLIKK } \\
\text { TARİHİ }\end{array}$ & $\begin{array}{l}\text { KANUN } \\
\text { NO }\end{array}$ & $\begin{array}{l}\text { DEĞİŞTİRILEN } \\
\text { MADDELER }\end{array}$ & $\begin{array}{l}\text { EKLENEN } \\
\text { GEÇICI } \\
\text { MADDELER }\end{array}$ & $\begin{array}{l}\text { YÜRÜRLÜKTEN } \\
\text { KALDIRILAN } \\
\text { MADDELER }\end{array}$ \\
\hline 1 & 6 Kasım 1969 & 1188 & 68. madde & - & Geçici 11. madde \\
\hline 2 & 17 Nisan 1970 & 1254 & 73. madde & 11. madde & - \\
\hline 3 & 17 Nisan 1970 & 1255 & 131. madde & - & - \\
\hline 4 & $\begin{array}{l}\text { 30 Haziran } \\
1971\end{array}$ & 1421 & $56,82$. maddeler & - & - \\
\hline 5 & 20 Eylül 1971 & 1488 & $\begin{array}{l}11,15,19,22,26,29,30,32, \\
38,46,60,61,64,89,110, \\
111,114,119,120,121,124, \\
127,134,137,138,139,140, \\
141,143,144,145,147,149, \\
151,152 . \text { maddeler }\end{array}$ & $\begin{array}{l}12,13,14,15, \\
\text { 16, 17, 18, 19, } \\
\text { 20. maddeler }\end{array}$ & - \\
\hline 6 & 15 Mart 1973 & 1699 & $\begin{array}{l}\text { 30, } 57,136,138,148 \\
\text { maddeler }\end{array}$ & $\begin{array}{l}21,22 . \\
\text { maddeler }\end{array}$ & \\
\hline 7 & 16 Nisan 1974 & 1801 & 68. madde & - & Geçici 11. madde \\
\hline
\end{tabular}

111961 Anayasası'nda yapılan değişiklikler, dört kez Anayasa Mahkemesi’ne (1970, 1975, 1976, 1977) gitmiş ve ilgili maddeler $(38,68,137,138)$ iptal edilmiştir. 